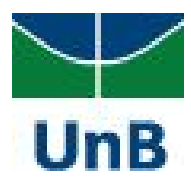

Universidade de Brasília

Faculdade de Educação

\title{
A ATUAÇÃO DE EDUCADORES SOCIAIS NO PROCESSO DE INCLUSÃO DE ALUNOS COM DEFICIÊNCIA VISUAL NOS ANOS INICIAIS DO DISTRITO FEDERAL
}

JOSELENA PATRÍCIO DA SILVA SANTOS

BRASÍLIA/2019 


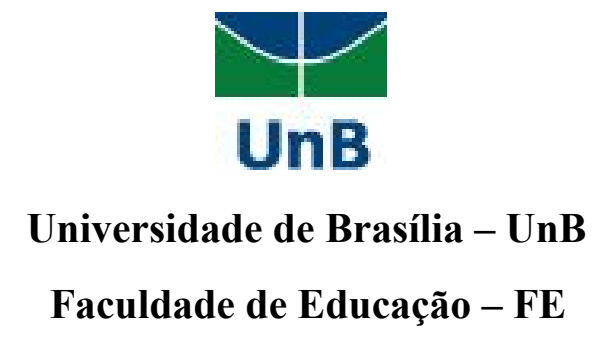

JOSELENA PATRÍCIO DA SILVA SANTOS

\section{A ATUAÇÃO DE EDUCADORES SOCIAIS NO PROCESSO DE INCLUSÃO DE ALUNOS COM DEFICIÊNCIA VISUAL NOS ANOS INICIAIS DO DISTRITO FEDERAL}

Trabalho de conclusão de curso apresentado à Banca Examinadora da Faculdade de Educação como exigência final para obtenção do título de Pedagoga.

Orientadora: Profa. Dra. Sinara Pollom Zardo 
JOSELENA PATRÍCIO DA SILVA SANTOS

\section{A ATUAÇÃO DE EDUCADORES SOCIAIS NO PROCESSO DE INCLUSÃO DE ALUNOS COM DEFICIÊNCIA VISUAL NOS ANOS INICIAIS DO DISTRITO FEDERAL}

Trabalho de Conclusão de Curso submetido à Faculdade de Educação da Universidade de Brasília, como requisito para a obtenção do grau de Pedagoga. Apresentação ocorrida em 12019 .

Aprovada pela banca formada pelos professores:

Profa. Dra. Sinara Pollom Zardo (Orientadora)

Profa. Dra. Cátia Piccolo Viero Devechi (Examinadora FE/UnB)

Profa. Ms. Flávia Ramos Cândido (Examinadora SEEDF)

BRASÍLIA/2019 


\section{DEDICATÓRIA}

Ao meu marido, família e amigos "Presenças", que me deram coragem para questionar realidades ainda tímidas e propor sempre um mundo de mudanças e possibilidades. 


\section{AGRADECIMENTOS}

Agradeço primeiramente à Deus pela vida e por me presentear com minha família e amigos, pessoas que estiveram comigo a todo tempo me apoiando para a realização de meu sonho.

Ao meu esposo pelo suporte, confiança, cumplicidade, cuidado, por me fortalecer e estar comigo em todos os momentos de estudos, me auxiliando e compartilhando conhecimentos. Agradeço por ser o alicerce de nossa casa.

Ao meu filho por ter me acompanhado desde o início dessa longa caminhada, mesmo sem saber, foi peça fundamental para que eu não desistisse e continuasse a caminhada.

Meus sobrinhos que, como meu filho, foram por muitas vezes objeto de pesquisa durante a graduação.

Aos amigos e em especial ao grupo "PRESENÇA" que me inspira com sua amizade e irmandade e que me apoiaram sendo minha família quando foi necessário para continuar a trajetória acadêmica, me dando exemplo de persistência, coragem, fé e amor.

Aos professores e a instituição "UnB" que me acolheram e contribuíram com um vasto conhecimento que me foi passado, com respeito, ética, profissionalismo e amizade.

Agradeço à gestão da escola, professores e educadores sociais pela contribuição e participação na pesquisa, aos funcionários e alunos que me acolheram com tanto carinho, dedicação e acreditaram no meu trabalho. Em especial, a professora Katerynne, por toda a experiência compartilhada, doação, exemplo de profissionalismo e toda amizade.

A minha orientadora que esteve comigo durante todo o tempo de pesquisa, me orientando pacientemente, acreditando em mim, me encorajando e acima de tudo dando o suporte necessário, sempre com muito carinho, amizade e confiando em meu trabalho. Agradeço por todo apoio, dedicação e profissionalismo na realização desse sonho. 
A inclusão acontece quando. . .

"Se aprende com as diferenças e não com as igualdades".

Paulo Freire 


\section{RESUMO}

O presente trabalho tem como objetivo geral compreender como se dá a atuação dos educadores sociais voluntários no acompanhamento de alunos com deficiência visual incluídos nos anos iniciais do ensino fundamental. Como objetivos específicos, foram elencados os seguintes: a) identificar o perfil dos profissionais que atuam no processo de inclusão escolar de alunos com deficiência visual nos anos iniciais do ensino fundamental; $b$ ) conhecer a perspectiva destes profissionais sobre a inclusão escolar e a organização do atendimento especializado; c) verificar a atuação dos educadores sociais voluntários e os desafios no processo de inclusão escolar de alunos com deficiência visual nos anos iniciais. Trata-se de uma pesquisa qualitativa, que utilizou os seguintes instrumentos para reunião dos dados: questionário de perfil, entrevista semiestruturada, observação e análise documental. Participaram da pesquisa cinco sujeitos: dois professores que atuam na sala de aula regular, uma professora itinerante que atua em sala de recursos e dois educadores sociais voluntários. Observou-se que o Programa Educador Social Voluntário se apresentou como uma ação de apoio aos estudantes da educação especial incluídos nos anos iniciais do ensino fundamental no Distrito Federal. No entanto, a formação prevista nas normativas do programa não tem acontecido, o que compromete a atuação dos educadores sociais voluntários com os estudantes com deficiência visual (cegueira e baixa visão), uma vez que os mesmos não apresentaram conhecimento sobre as necessidades educacionais específicas desse alunado e de recursos e serviços de acessibilidade.

Palavras-Chave: Educador Social Voluntário. Inclusão escolar. Deficiência visual. 


\begin{abstract}
This work evaluated the procedure of Volunteer Social Educator, a program managed by Regional Education Coordination from Government of Distrito Federal, under the thematic of inclusion of students with visual impairments in regular school classrooms. The experience lived through participant observation in a regular school that receives the social educator's volunteers to accompany students with visual impairment motivated the execution of this work, compelling the study and understanding of the federal and district laws that assert the rights in the educational service. The Volunteer Social Educator Program and the acting of its executors in the monitoring and support of visually impaired students were studied through observation in the school environment with field diary, semi-structured interviews with teachers and educators volunteers, documental analysis and verification of their daily performance. These procedures made it possible to understand how the social volunteer educator works in the process of including students with visual impairment and their contribution to teaching and learning in a public school in the Distrito Federal. It was observed the relevance and importance of the program, the shortcomings that it has and the requirement to think about strategies that can improve its acting in teaching and learning of students with visual impairment.
\end{abstract}

Keywords: Volunteer Social Educator. Scholar inclusion. Visual impairment. 


\section{LISTA DE SIGLAS E ABREVIATURAS}

AEE - Atendimento Educacional Especializado

CEEDV - Centro de Ensino Especial de Deficientes Visuais

CF - Constituição Federal

COETE - Coordenação de Políticas Educacionais Transversais

COSIE - Coordenação de Supervisão, Normas e Informações do Sistema de Ensino

CRE - Coordenação Regional de Ensino

DF - Distrito Federal

DIEE - Diretoria de Educação Especial

DV - Deficiência Visual

ECA - Estatuto da Criança e do Adolescente

EJA - Educação de Jovens e Adultos

ESV - Educador Social Voluntário

GIPEP - Gerência de Instrução Processual de Educação Profissional e Educação Especial

LBI - Lei Brasileira de Inclusão da Pessoa com Deficiência

LDB - Lei de Diretrizes e Bases da Educação Nacional

MEC - Ministério da Educação

ONU - Organização das Nações Unidas para a Educação, a Ciência e a Cultura

PAEE - Programa de Atendimento Educacional Especializado

PNEE - Política Nacional de Educação Especial

PPP - Projeto Político Pedagógico

SEEDF - Secretaria de Estado de Educação do Distrito Federal

SUBEB - Subsecretaria de Educação Básica

SUPLAV - Subsecretaria de Planejamento, Acompanhamento e Avaliação

TA - Tecnologia Assistiva

TEA - Transtorno do Espectro Autista

UEG - Universidade Estadual do Goiás

UFMG - Universidade Federal de Minas Gerais 
UNB - Universidade de Brasília 


\section{LISTA DE TABELAS}

Tabela 01 - Anexo I da Portaria do Programa ESV- Dos critérios de seleção e classificação 37

Tabela 02 - Anexo II da Portaria do Programa ESV- Pontuação da Entrevista 


\section{LISTA DE GRÁFICOS}

Gráfico 01 - Matrículas do Programa de Atendimento Educacional Especializado (PAEE) em classes comuns do ensino regular e em classes/escolas especiais (2006-2016)

Gráfico 02 - Percentual dos tipos de deficiência referenciados pela população com alguma deficiência - Distrito Federal, 2010.

Gráfico 03 - Idade, escolaridade, formação específica e tempo de educador dos entrevistados. 


\section{LISTA DE FIGURAS}

Figura 01 - Organograma da Secretaria de Estado de Educação do Distrito Federal 


\section{SUMÁRIO}

$\begin{array}{ll}\text { PARTE I } & 15\end{array}$

$\begin{array}{ll}\text { MEMORIAL } & 16\end{array}$

$\begin{array}{ll}\text { PARTE II } & 22\end{array}$

CONSIDERAÇÕES INICIAIS

CAPÍTULO I - A ORGANIZAÇÃO DA EDUCAÇÃO INCLUSIVA E DA EDUCAÇÃO ESPECIAL PARA ALUNOS COM DEFICIÊNCIA VISUAL DO DISTRITO FEDERAL 25

CAPÍTULO II - CONSIDERAÇÕES SOBRE O PROGRAMA EDUCADOR SOCIAL VOLUNTÁRIO $\quad 34$

CAPÍTULO III. PROCEDIMENTOS METODOLÓGICOS 40

CAPÍTULO IV - ANÁLISE DE DADOS 44

4.1 Perfil dos participantes da pesquisa e formação específica na área da deficiência visual 44

4.2 A inclusão escolar dos alunos com deficiência visual na escola pesquisada 46

4.3 O atendimento educacional especializado para os alunos com deficiência visual 49

4.4 A atuação dos educadores sociais na inclusão escolar de alunos com deficiência visual 51

4.5 Desafios no processo de inclusão escolar de alunos com deficiência visual 55

CONSIDERAÇÕES FINAIS $\quad 60$

$\begin{array}{ll}\text { PARTE III } & 61\end{array}$

$\begin{array}{ll}\text { PERSPECTIVAS FUTURAS } & 62\end{array}$

$\begin{array}{ll}\text { REFERENNCIAS } & 63\end{array}$

APÊNDICE A - TERMO DE CONSENTIMENTO LIVRE E ESCLARECIDO 65

APÊNDICE B - Questionário de perfil do entrevistado - professor(a) da sala de recursos 66

APÊNDICE C - Questionário de perfil do entrevistado - professor(a) da sala de aula regular 68

APÊNDICE D - Questionário de perfil do entrevistado - educador(a) social voluntário 70

APÊNDICE F - Roteiro de entrevista educador(a) social 73 
PARTE I 


\section{MEMORIAL}

Dou início a este trabalho contando um pouco de minha história até aqui. Me chamo Joselena, tenho 34 anos e nasci em Aimorés/MG; dos dois aos dezenove anos residi em Belo Horizonte/MG com meus pais e irmãos. Meu pai é mineiro de Bias Fortes/MG e minha mãe de Aimorés/MG. Ambos foram para Belo Horizonte em busca de melhores oportunidades. Meus irmãos, Paulo e Henrique, são mais velhos e fruto do primeiro matrimônio de minha mãe.

Iniciei os estudos aos seis anos de idade com apoio de uma bolsa de estudos no Instituto Educacional Primeiros Passos, na cidade de Contagem/MG. Na época não era tão acessível ingressar no jardim de infância da rede pública e recorrer a políticos para conseguir uma bolsa era essencial. A escola era bem legal, mas não me sentia parte dela por se tratar de uma escola mais elitizada e minha família era de classe mais humilde. Eu era a única bolsista da escola, contudo era bom estar naquele ambiente, onde eu sabia que aprenderia muita coisa.

Da $1^{\mathrm{a}}$ a $5^{\mathrm{a}}$ série estudei na Escola Estadual do Bairro Industrial São Luiz, localizada em Contagem/MG. Hoje a escola se chama Escola Estadual Lívia Mara de Castro, homenagem a uma amiga da época que faleceu de leucemia. Lembro-me de cada professora que tive nessa escola, inclusive a minha professora da $1^{\mathrm{a}}$ e $2^{\mathrm{a}}$ séries era a proprietária do Jardim de Infância. Lá comecei a vivenciar coisas mais prazerosas e principalmente fazer amigos, pois me sentia pertencente àquele ambiente. Jamais esqueço o quanto fui feliz e me desenvolvi nesses dois anos.

Ainda hoje me recordo da minha professora da $1^{\mathrm{a}}$ e $2^{\mathrm{a}}$ séries, que me acolheu de braços abertos, aceitou minha demora em copiar as coisas, minha falta de atenção e me ajudou muito. Essa professora tinha algo a mais, algo diferente que a tornava especial. Talvez ela tenha me chamado a atenção pela pequena estatura ou a voz diferente, quem sabe? No fundo, eu me via nela, diferente das demais professoras daquele ambiente. Mesmo com 1,50m de altura, que por vezes era confundida com os alunos, ela conseguia direcionar a turma e também a vice direção daquela instituição. Capacitada, inteligente, abraço gostoso e uma líder e tanto! Ter ela como professora, era simplesmente a melhor coisa que poderia ter me acontecido.

$\mathrm{Na} 4^{\mathrm{a}}$ série também desfrutei de uma excelente professora, onde a mesma notava todas as minhas dificuldades e sempre estava pronta para me dar assistência, mesmo fora do horário 
da aula. Eu tinha muita dificuldade na aprendizagem e um professor que se atentasse para isso era gratificante pra mim. Como não amar a professora que dedica seu tempo livre a tirar minhas dúvidas, mesmo no seu descanso? Essa professora procurou ser uma das melhores amigas da minha mãe, que era ajudante de serviços gerais na mesma escola para mostrar a ela a importância do estudo, da continuidade do mesmo e principalmente, incentivou que a minha mãe terminasse o ensino fundamental, na época, $8^{\mathrm{a}}$ série.

Contudo, como mudar a cabeça de pessoas que não entendiam a importância do estudo por não ter tido a oportunidade? Meu pai estudou até a $3^{\mathrm{a}}$ série, enquanto minha mãe tinha a $4^{\mathrm{a}}$ série e depois, com o incentivo da minha professora, terminou a $8^{\mathrm{a}}$ série. Fui muito feliz nessa escola, foi o lugar onde fiz mais amigos, amigos que me acompanham até hoje.

Fui para a Escola Estadual Padre Camargo, localizada em Contagem em Minas Gerais, que era uma escola extremamente organizada. Refiz a $5^{\text {a }}$ série, pois repeti o ano devido às faltas por problemas de saúde. Nessa escola conclui a $5^{\mathrm{a}}$ e metade da $6^{\mathrm{a}}$ série e pude perceber as diferentes formas de funcionamento das instituições de ensino.

No segundo bimestre da $6^{\circ}$ série enfrentei mais uma mudança de escola, seria a última, pois dessa vez terminaria meu ciclo de ensino básico. Conseguimos comprar um imóvel em Belo Horizonte/MG e então terminei o meu ensino fundamental e ensino médio na Escola Estadual Ministro Alfredo de Vilhena Valladão. Essa escola e mudança me trouxeram muitos desafios que vieram acompanhados de muitas alegrias. Professores, amigos, primeiros empregos que marcaram minha vida e que ainda hoje se fazem presentes. E como não poderia ser diferente, também conheci uma pessoa que se tornou namorado e hoje marido.

Depois desse tropeço em uma feira de cultura da escola, onde nos conhecemos, cinco anos depois nos casamos, mudamos para Brasília/DF devido a uma transferência ocorrida pelo trabalho dele. Meu marido que cursava Matemática na Universidade Federal de Minas Gerais (UFMG), deu continuidade aos estudos na Universidade de Brasília (UnB), mas logo decidiu mudar de curso e encarou o curso de Computação.

Em Brasília, tivemos a oportunidade de conhecer pessoas que estavam na mesma situação que a gente: jovens, longe de familiares e iniciando uma vida independente. Foi onde aumentamos nosso círculo de amizades, onde nos encontramos e partilhamos momentos maravilhosos com pessoas que passaram a ser nossa família. 
Comecei a trabalhar na área administrativa em uma escola de língua estrangeira no Paranoá, escola que me proporcionou um contato com a área da Educação, me fez apaixonar pelas crianças e enxergar o aluno além da sala de aula. Trabalhava no serviço administrativo, porém, a parte de organização pedagógica também era comigo.

Pensava que nunca conseguiria dar continuidade aos estudos pela minha dificuldade de aprendizagem, mas depois de 10 anos sem estudar, muita insistência e uma ajudinha do meu marido que fez minha inscrição e me colocou dentro da sala para fazer a prova do vestibular, ingressei na UnB. Fiz a prova e simplesmente esqueci. Mal sabia que ele estava lembrando, imprimiu o resultado, entregou em minhas mãos e eu, sem entender, recebi a notícia que havia sido aprovada em Pedagogia, pelo vestibular do ano de 2013.

Para falar a verdade, ainda hoje parece que a ficha não caiu. Era o curso que eu queria, não imaginava conseguir nem na universidade privada e Deus me honrou e me colocou em uma universidade pública. Quanto orgulho de mim mesma por continuar na rede pública!

Nesse ano, Deus não me poupou e junto com a graduação, me presenteou com uma gravidez. "Como assim! Nem sabia que eu poderia engravidar! Dez anos de casada, sem anticoncepcional e agora engravidar? Como fazer essas duas coisas ao mesmo tempo? Isso é impossível!’".

Mas como Deus sabe de todas as coisas, ele nos dá e nos ensina como fazer.

Iniciei o curso e fui me apaixonando cada vez mais. As matérias se encaixaram direitinho com minha condição da época. No $1^{\mathrm{o}}$ semestre, cursei as matérias Perspectiva do Desenvolvimento Humano e Oficina Vivencial que me ajudaram muito, tanto com a gravidez, como também no meu autoconhecimento. Encontrei professores maravilhosos que me ajudaram nesse processo e também me prepararam para a maternidade.

No $2^{\circ}$ semestre, cursei a disciplina Aprendizagem e Desenvolvimento da Pessoa com Necessidades Educacionais Especiais e comecei a perceber que a Pedagogia está muito além do que havia pensado. Juntamente com minhas novas experiências no campo do ensino e aprendizagem de crianças com deficiência e a inclusão, pude acompanhar o Trabalho de Conclusão de Curso (TCC) do meu marido e percebi a dificuldade e escassez de materiais voltados ao ensino dos alunos com deficiência visual. Começaram as pesquisas e visitas dele 
ao Centro de Ensino Especial de Deficientes Visual (CEEDV) e eu não perdia essas oportunidades de estar junto.

Vieram meus trabalhos de campo, mais disciplinas, projetos e então experimentei o estágio obrigatório no Hospital Universitário de Brasília (HUB). Não imaginava que me encontraria ali, me apaixonei por essa pedagogia que até então era desconhecida para mim. Dentro dessa descoberta, me redescobri quando uma mãe de uma criança de 4 anos e com deficiência visual me questionou se seria possível o filho dela estudar com crianças "normais". Naquele momento só consegui responder que "podemos tudo" e logo fui até a pedagoga para que pudesse me auxiliar. A pedagoga, com um "sorriso amarelo", disse que "o problema da educação está aí, não saímos sabendo de tudo e não estamos preparados para encarar esses tipos de alunos”. Depois dessa experiência, minhas lembranças de infância vieram em meus pensamentos. Lembrei de tios da minha mãe que eu visitava quando criança e eles nasceram surdos e no decorrer da vida, ainda muito jovens, perderam a visão. Foram pessoas dependentes para tudo, nossa comunicação era uma "libras adaptada", ainda tenho dúvidas se realmente a gente conseguia ter um diálogo com a "libras adaptada", pois moravam em lugares isolados e o contato era apenas com familiares que sabiam que eles existiam naquele lugar afastado.

Me coloquei no lugar deles e principalmente da criança que tinha acabado de conhecer. Assim, procurei, através de indicações de amigos um professor que conhecesse e amasse essa área para eu dar continuidade aos projetos. Encontrei essa professora que hoje me faz buscar mais sobre o assunto, que me colocou para fazer cursos e principalmente que aguçou minha vontade de conhecer o ensino em uma escola regular para esses meninos com deficiência visual.

Com esse novo despertar, procurei uma escola que não era famosa e muito menos uma referência nessa área, porém, era o polo de deficiência visual e recebia alunos com essa especificidade das regiões do Paranoá, Itapoã, Sobradinho dos Melos, Lago Norte e condomínios. Era simplesmente uma escola comum que recebia esses alunos e também os Educadores Sociais Voluntários (ESV), chamados de monitores pela instituição.

Iniciei a disciplina de Projeto 4-1 acompanhando 2 alunos com deficiência visual e um deles com uma doença chamada Síndrome de Marfan. Essa doença é hereditária e afeta o 
tecido conjuntivo responsável pelo fortalecimento das estruturas do corpo; geralmente atinge o coração, os olhos, os vasos sanguíneos e também o esqueleto. (https://www. minhavida. com. br/saude/temas/síndrome-de-marfan)

O aluno com Marfan tinha problemas de aprendizagem e mesmo no $4^{\circ}$ ano, não reconhecia letras e números devido à sua condição de saúde. É popular na escola e a preocupação maior é sobre a saúde do menino. Isso me chamou muita atenção, pois a aprendizagem e a capacidade de aprender desse aluno já não era o mais importante naquele ambiente.

No desenvolvimento do relatório de conclusão do estágio, na análise do PPP (Projeto Político Pedagógico) da escola, senti falta de um olhar mais apurado para a inclusão dos alunos com deficiência. Contudo, mais uma coisa contribuindo e eu a cada dia pensando mais sobre minha temática de pesquisa. Comecei a atuar como voluntária na escola e no decorrer dessas visitas buscava criar, junto com a professora, meios para produzir materiais de apoio para esses alunos.

A cada semestre, buscava mais matérias voltadas ao atendimento de alunos com deficiência visual na Faculdade de Educação (FE) e mais recursos para usar na sala de aula. Meu tempo de matérias optativas e módulos livres foram voltados a aprender a fazer materiais de apoio, jogos adaptados e assim abrir um leque de possibilidades de ensino para os alunos com deficiência visual.

No decorrer dos semestres, sempre esbarrava na temática da deficiência visual, mesmo quando a matéria não tinha muito a ver com inclusão. Ao me apropriar do projeto do Governo do Distrito Federal (GDF), a cada dia me fazia mais curiosa sobre o Programa do Educador Social Voluntário (ESV).

Mesmo buscando matérias na área, faltava conseguir decidir a minha pesquisa em si. Então, minha orientadora sugeriu que eu fizesse a disciplina de Seminário de Final de curso, foi quando conheci a professora Cátia Piccolo que com a ajuda dela e da disciplina, pude fechar com chave de ouro a escolha do tema e juntamente com minha orientadora desenvolvemos a pesquisa que muito me orgulha. 
Com todo encanto da área e percebendo algumas lacunas em minha formação que geraram questionamentos durante minha trajetória acadêmica, senti a necessidade de buscar compreender como é feito o acompanhamento educacional de alunos com deficiência visual pelo Programa do Educador Social Voluntário nos anos iniciais do ensino fundamental de uma escola de ensino regular. Sendo assim, escolhi este tema como trabalho de conclusão de curso. 
PARTE II 


\section{CONSIDERAÇÕES INICIAIS}

Na última década, principalmente após a ratificação pelo Brasil da Convenção da ONU sobre os Direitos das Pessoas com Deficiência por meio dos Decretos 186/2008 e 6.949/2009, podemos acompanhar a ampliação dos marcos normativos que asseguram o direito à educação para as pessoas com deficiência, com vistas à efetivação dos direitos constitucionais e estabelecidos na Lei de Diretrizes e Bases da Educação Nacional (LDB) Lei $N^{0} 9.394 / 1996$.

No âmbito da educação nacional, podemos destacar a publicação da Política Nacional de Educação Especial na Perspectiva da Educação Inclusiva (MEC, 2008), que subsidiou a regulamentação do Decreto $\mathrm{N}^{\mathrm{o}}$ 7.611/2011, e que afirmam o direito à escolarização e ao atendimento educacional especializado (AEE) para alunos com deficiência, transtornos globais do desenvolvimento e altas habilidades/superdotação. Na perspectiva de tais marcos legais, esse atendimento objetiva complementar ou suplementar à escolarização dos alunos da educação especial e subsidiar a organização dos espaços, materiais acessíveis e orientação para o corpo docente da escola para promover a inclusão desse desses estudantes na escola.

No Distrito Federal, a organização do sistema de ensino para a inclusão de estudantes com deficiência está amparada, dentre outras normativas, nas Orientações Pedagógicas da Educação Especial (2010) e no Currículo em Movimento da Educação Básica - Educação Especial (2018). Considerando a positivação do direito à educação para os estudantes da educação especial e o aumento significativo de matrículas nas escolas regulares, a Secretaria de Estado de Educação do Distrito Federal (SEEDF), juntamente com o Governo do Distrito Federal (GDF), criou em 2015 o Programa do Educador Social Voluntário (ESV) (Decreto N 37.010/2015). Dentre seus objetivos, o Programa prevê a oferta de suporte aos estudantes com deficiência e transtorno global do desenvolvimento, para o atendimento das suas habilidades adaptativas relacionadas à alimentação, locomoção e higienização, nas unidades escolares da rede pública do DF.

Durante a observação em uma escola, através de uma disciplina do curso de pedagogia da UnB, foi possível observar que a função de apoio à escolarização aos estudantes 
com deficiência visual foi deliberada aos educadores sociais voluntários. Esse aspecto chamou a atenção da pesquisadora, por entender que a atuação de profissionais na inclusão escolar com estudantes com deficiência requer uma formação específica, com conhecimentos sobre recursos e serviços de acessibilidade. Como se dá a atuação dos educadores sociais voluntários com os alunos com deficiência visual incluídos nos anos iniciais do ensino fundamental? Eles possuem formação na área da educação especial? Quais desafios enfrentam? Como os professores das salas de aula regulares concebem a atuação desses profissionais?

Os questionamentos acima apresentados orientaram o objetivo geral da pesquisa, que consiste em: compreender como se dá a atuação dos educadores sociais voluntários com os alunos com deficiência visual incluídos nos anos iniciais do ensino fundamental. Como objetivos específicos, foram elencados os seguintes: a) identificar o perfil dos profissionais que atuam no processo de inclusão escolar de alunos com deficiência visual nos anos iniciais do ensino fundamental; b) conhecer a perspectiva destes profissionais sobre a inclusão escolar e a organização do atendimento especializado; c) verificar a atuação dos educadores sociais voluntários e os desafios no processo de inclusão escolar de alunos com deficiência visual nos anos iniciais.

O presente trabalho de conclusão de curso está organizado da seguinte forma: a primeira parte apresenta a trajetória biográfico-formativa da autora; a segunda parte apresenta a pesquisa realizada, contendo os objetivos, procedimentos metodológicos, referencial teórico e análise de dados, organizados em quatro capítulos; e a terceira parte apresenta as perspectivas futuras de formação e atuação profissional. 


\section{CAPÍTULO I - A ORGANIZAÇÃO DA EDUCAÇÃO INCLUSIVA E DA EDUCAÇÃO ESPECIAL PARA ALUNOS COM DEFICIÊNCIA VISUAL DO DISTRITO FEDERAL}

Neste capítulo será abordado o tema da educação inclusiva e a organização da educação especial no sistema de ensino do Distrito Federal, principalmente para os estudantes com deficiência visual (cegueira e baixa visão).

A perspectiva da educação inclusiva emerge nos anos 90 do século passado, principalmente por movimentos internacionais que se constituem a partir um discurso de “educação para todos”, a exemplo da Conferência Mundial de Educação para Todos, realizada em 1990 em Jomtiem, e da Conferência Mundial sobre as Necessidades Educativas Especiais, realizada em 1994, em Salamanca, tida como a certidão de nascimento da proposta de educação inclusiva (NOZU et all, 2017).

No mesmo contexto Zardo (ZARDO, 2012) também relembra que nas no mesmo período intensificaram-se as propostas de democratização e de movimentos que comportavam a busca pela garantia do direito à educação para os cidadãos excluídos do sistema escolar.

A organização de sistemas educacionais inclusivos requer que sejam considerados aspectos relacionados à diversidade e a diferença dos estudantes, incluindo aspectos relacionados às características, interesses, habilidades e potencialidades de todos, independentemente de suas condições físicas, sensoriais ou intelectuais (UNESCO, 1994). Assim, todas as pessoas são destinatárias da educação inclusiva. Estes aspectos relacionados à diversidade remetiam também aos fundamentos políticos e filosóficos que evidenciam a diferença humana e vão de encontro à homogeneização da construção do conhecimento na instituição escolar (ZARDO, 2012).

Neste contexto o Governo do Distrito Federal, respeitando o que fora definido na Lei de Diretrizes e Bases (LDB, 1996), prevê a organização da educação especial no sistema de ensino como uma modalidade voltada para estudantes com deficiência, transtornos globais do desenvolvimento e altas habilidades/superdotação (cf. Art. 58). A definição do público alvo 
da educação especial e do atendimento educacional especializado como conjunto de recursos e serviços que promovem acessibilidade aos estudantes também está prevista na Política Nacional de Educação Especial na Perspectiva da Educação Inclusiva (MEC, 2008) e nas Diretrizes CNE/CEB No 4/2009, que orientam a organização do atendimento educacional especializado.

Um dos reflexos dessas normativas que positivam o direito à educação para os alunos da educação especial encontra-se no considerável aumento de matrículas deste alunado em salas comuns do ensino regular, conforme exibido no Gráfico 01.

Gráfico 01 - Matrículas nacionais do Programa de Atendimento Educacional Especializado (PAEE) em classes comuns do ensino regular e em classes/escolas especiais (2006-2018)

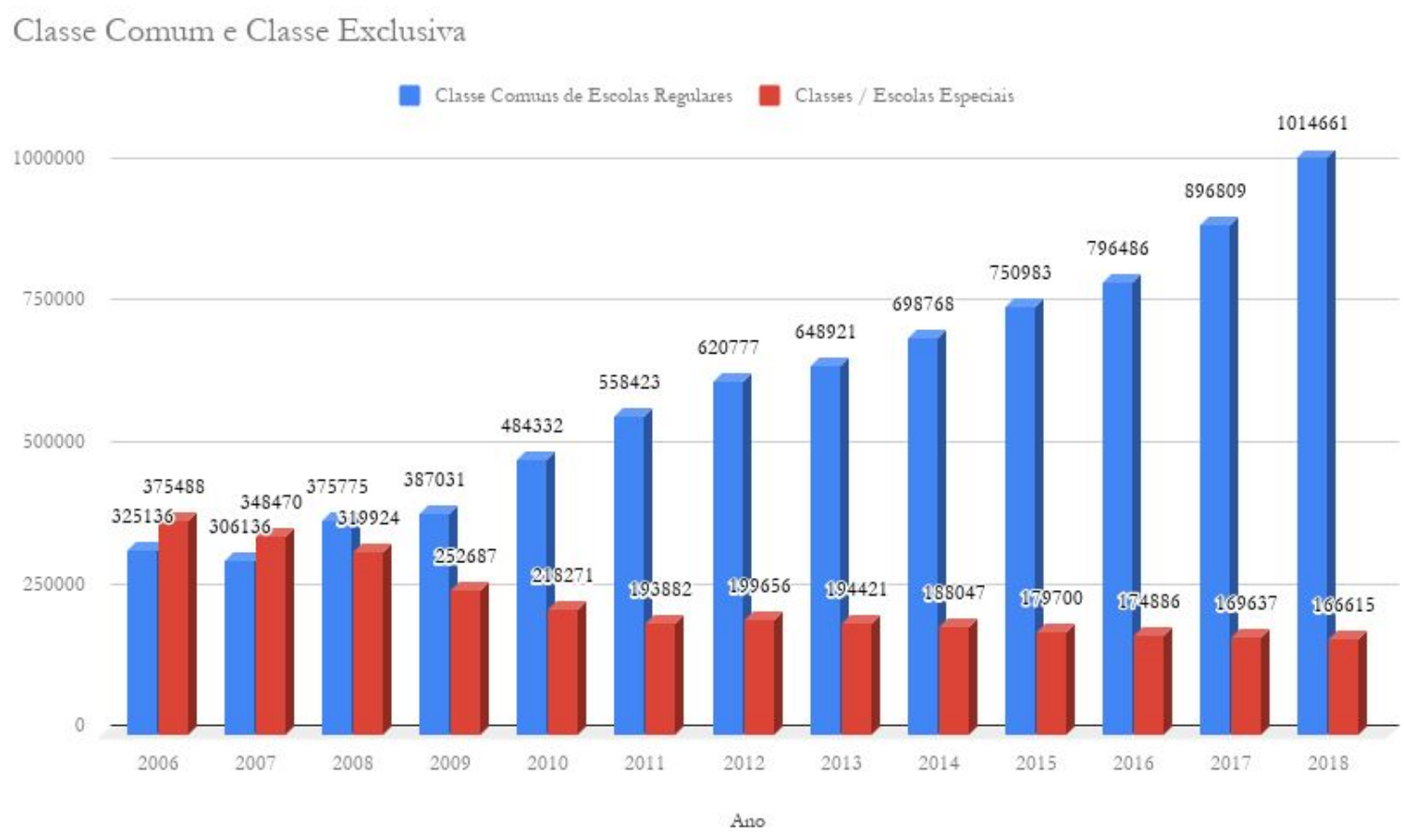

Fonte: Autora adaptado do Censo Escolar (INEP)

No âmbito do Distrito Federal, segundo a Companhia de Planejamento do Distrito Federal (CODEPLAN), em 2010, havia 14.119 estudantes com necessidades educacionais 
específicas matriculados, dos quais $8,99 \%$ estavam em escolas especializadas, $25,67 \%$ em classes especiais e 65,34\% em classes comuns (CODEPLAN, 2013).

Estes estudantes estão distribuídos dentre as porcentagens exibidas no Gráfico 02, que mostra, por exemplo, que os deficientes visuais são $63,71 \%$ dos deficientes do Distrito Federal, com base no Censo Demográfico de 2010 (IBGE, 2010).

Gráfico 02 - Percentual dos tipos de deficiência referenciados pela população com alguma deficiência - Distrito Federal, 2010.

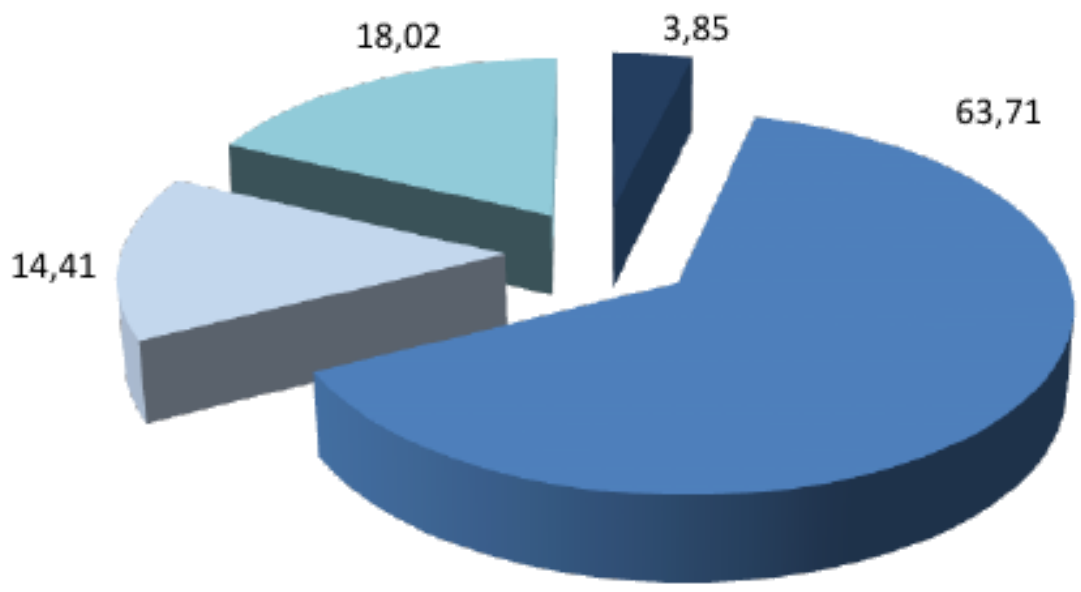

Mental/intelectual

Deficiência visual

Deficiência auditiva

Deficiência motora

Fonte: Instituto Brasileiro de Geografia e Estatística (IBGE), Censo Demográfico 2010

Observa-se a incidência de pessoas com deficiência visual, conforme revela o Gráfico 02. Entretanto, deve-se destacar que o Censo do IBGE contabiliza, por amostragem, a população com deficiência visual e que a pergunta do instrumento de coleta de dados indaga sobre a graduação de dificuldade que a pessoa tem para enxergar. Por conseguinte, verifica-se que a deficiência visual predomina em pessoas com mais de 60 anos, devido a diminuição da acuidade visual causada pelo envelhecimento.

Esta perspectiva de educação inclusiva, que busca inserir o aluno em uma sala de aula, considerando suas características e não suas deficiências, passa a integrar o Currículo em Movimento (2018) do Governo do Distrito Federal que diz:

Nesta direção, há grande expectativa em torno da prática inclusiva; sobretudo, há premência de atitudes e de ações pessoais e coletivas para a 
real inclusão de todos os estudantes - independentemente de seu talento, deficiência, origem socioeconômica ou cultural - em salas de aula provedoras, em que as necessidades desses alunos sejam satisfeitas (apud, STAINBACK, 1999).

Assim o Governo do Distrito Federal viu-se desafiado a organizar seu sistema de ensino na perspectiva da educação inclusiva, buscando o equilíbrio e harmonia em sua proposta educativa para que assim atenda a necessidade de todos alunos respeitando suas especificidades e necessidades individuais, ultrapassando quaisquer que sejam suas limitações e evidenciando suas potencialidades (Currículo em Movimento, 2018).

As orientações curriculares do DF, amparadas nas normativas nacionais, destacam três níveis de adaptações para promover a inclusão escolar.

- Adaptações relativas a projeto pedagógico (currículo escolar), que devem focalizar, principalmente, organização escolar e serviços de apoio, propiciando condições estruturais que possam ocorrer em nível de sala de aula e em nível individual. • Adaptações relativas ao currículo da classe, que se referem principalmente à programação de atividades elaboradas para sala de aula. • Adaptações individualizadas de currículo, que focalizam a atuação do professor na avaliação e atendimento a cada aluno (Currículo em Movimento, 2018)

Este terceiro nível, em particular, têm relação direta com o contexto deste trabalho e é contemplado por preocupação com a formação de profissionais capazes de desenvolver uma educação verdadeiramente inclusiva, combatendo um currículo rígido e estereotipado (Currículo em Movimento, 2018, apud Oliveira e Costa, 2002). No entanto, deve-se destacar que a adaptação curricular não pode ser compreendida como 'redução' de currículo e que o direito à educação para as pessoas com deficiência deve ser promovido pela via de um currículo que seja acessível para todos.

Em relação à organização e estrutura para garantir o ensino a sua população, o Governo do Distrito Federal (GDF) conta com uma Secretaria de Estado de Educação (SEEDF) que possui competências acerca da educação básica suas etapas e modalidades, da educação superior, do apoio ao estudante e da formação e capacitação de servidores. À Secretaria de Educação do Distrito Federal compete a responsabilidade pelas políticas públicas educacionais e administração superior da Rede Pública de Ensino do Distrito Federal (SEEDF, Regimento Interno, 2018). 
A Secretaria de Educação do Distrito federal se organiza conforme a Figura 01: vale ressaltar que a Subsecretaria de Educação Básica é composta, dentre outras, pela Diretoria de Educação Especial (DIEE) da Coordenação de Políticas Educacionais Transversais (COETE).

Figura 01 - Organograma da Secretaria de Estado de Educação do Distrito Federal

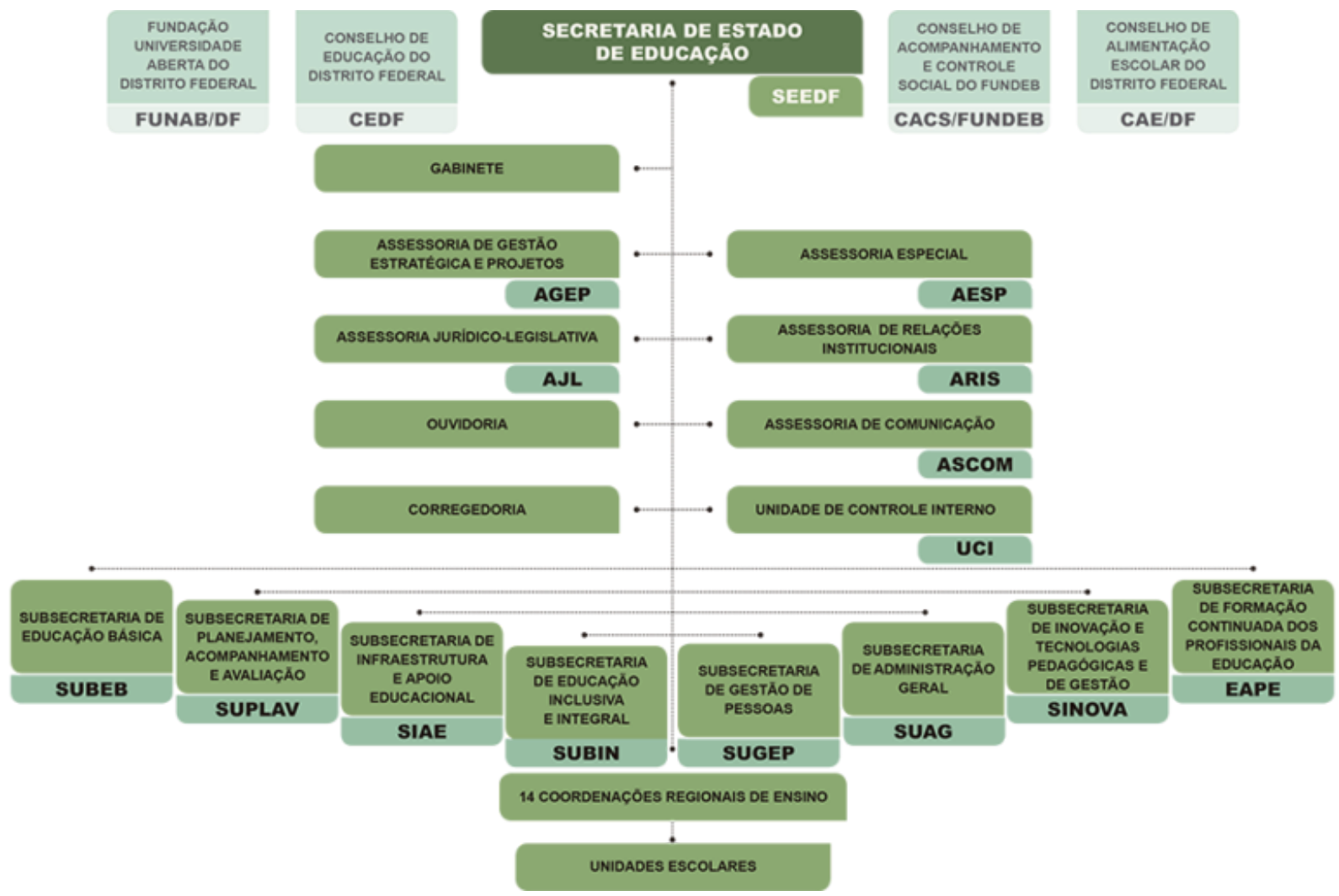

Fonte: SEEDF

À Diretoria de Educação Especial (DIEE), dentre outras atribuições, compete “propor, orientar e acompanhar a realização de pesquisas, estudos e experiências para subsidiar a prática pedagógica nas Unidades de Ensino (UEs) inclusivas, nos Centros de Ensino Especial (CEE) e nas instituições educacionais parceiras ou similares" (SEEDF, Regimento Interno, 2018). Especificamente nas portarias anuais de criação do Programa Educador Social Voluntário, foco deste trabalho, não há referência explícita da atuação da DIEE, mas sim as Coordenações das Regionais de Ensino (CREs) que conforme o organograma da Figura 01 são hierarquicamente subordinadas à Subsecretaria de Educação Básica (SUBEB) da qual faz parte. 
Ainda na estrutura da SEEDF existem a Gerência de Instrução Processual de Educação Profissional e Educação Especial (GIPEP) pertencente à Coordenação de Supervisão, Normas e Informações do Sistema de Ensino (COSIE), situada na Subsecretaria de Planejamento, Acompanhamento e Avaliação (SUPLAV) (SEEDF, Regimento Interno, 2018).

Para atender as necessidades dos alunos com deficiência, em especial a visual, foco desse trabalho, primeiro é preciso recorrer às informações às Orientações Pedagógicas da Educação Especial (SEEDF, Educação Especial, 2010) que revisa Plano Orientador das Ações de Educação Especial nas Escolas Públicas do Distrito Federal, publicado em 2006, e visa:

[...] a atender às atualizações da legislação e às adequações à Política Nacional da Educação Especial na Perspectiva de Educação Inclusiva de 2008 do Ministério da Educação, bem como contemplar o previsto na avaliação institucional desta Secretaria de Estado de Educação para Educação Especial por meio do Sistema de Avaliação do Desempenho das Instituições Educacionais do Sistema de Ensino do Distrito Federal SIADE. (SEEDF, Educação Especial, 2010)

Nas Orientações Pedagógicas da Educação Especial (SEEDF, 2010), são elencadas as seguintes atividades a serem desenvolvidas nas salas de recursos para estudantes com deficiência visual (cegueira e baixa visão):

- Sala de Recursos Específica para Estudante com Deficiência Visual: são atividades desenvolvidas em sala de recursos específica para atendimento ao estudante com deficiência visual;

- Promover e apoiar a alfabetização e o aprendizado pelo Sistema Braille;

- Realizar a transcrição de materiais, Braille/tinta, tinta/Braille, e produzir gravação sonora de textos;

- Realizar adaptação de gráficos, mapas, tabelas e outros materiais didáticos para uso de estudantes cegos;

- Promover a utilização de recursos ópticos (lupas manuais e eletrônicas) e não ópticos (cadernos de pauta ampliada, iluminação, lápis e canetas adequadas);

- Adaptar material em caracteres ampliados para uso de estudantes com baixa visão, além de disponibilizar outros materiais didáticos; 
- Desenvolver técnicas e vivências de orientação e de mobilidade e atividades da vida diária para autonomia e para independência;

- Desenvolver a competência do estudante para o uso do Soroban;

- Promover adequações necessárias para o uso de tecnologias de informação e de comunicação;

- Atuar como docente nas atividades de complementação ou de suplementação curricular específica;

- Atuar de forma colaborativa com o professor da classe comum para a definição de estratégias pedagógicas que favoreçam o acesso do estudante com deficiência ao currículo e a sua interação no grupo;

- Promover as condições de inclusão desses estudantes em todas as atividades da instituição educacional;

- Orientar as famílias para o seu envolvimento e a sua participação no processo educacional;

- Informar à comunidade escolar quanto à legislação e às normas educacionais vigentes asseguradoras da inclusão educacional;

- Participar do processo de identificação e de avaliação pedagógica das necessidades especiais e de tomadas de decisões quanto ao apoio especializado necessário para o estudante;

- Preparar material específico para o uso dos estudantes na sala de recursos;

- Orientar a elaboração de material didático-pedagógico que possam ser utilizados pelos estudantes nas classes comuns;

- Indicar e orientar professores e gestores para o uso de equipamentos e de materiais específicos e de outros recursos existentes na família e na comunidade e articular, para que a proposta pedagógica da instituição educacional seja organizada coletivamente em prol de uma educação inclusiva; e

- Responsabilizar-se, juntamente com os docentes, pelas adequações curriculares, necessárias ao processo educacional do estudante com necessidade educacional especial. 
Especificamente sobre o atendimento educacional especializado voltado aos estudantes com deficiência visual (cegueira e baixa visão), têm-se como referência, no Distrito Federal, o Centro de Ensino Especial para Deficientes Visuais (CEEDV).

Em 1973, foi criado o setor especializado em deficientes visuais do Centro de Ensino Especial 02 de Brasília. Nesse ano foram registrados atendimentos a 25 estudantes. No ano de 1985, o estabelecimento - Escola para Deficientes Visuais - atendia 130 estudantes cegos ou com baixa visão, dentre esses, alguns com deficiências múltiplas. Outra ação importante realizada pela escola foi a do Professor Itinerante, que chegou a atender, naquele ano, 80 (oitenta) estudantes com deficiência visual integrados à rede regular de ensino. Com o aumento da demanda de estudantes, a Diretoria do Ensino Especial da antiga Fundação Educacional do Distrito Federal, atualmente Secretaria de Estado de Educação do Distrito Federal, solicitou à Diretoria Geral de Pedagogia a transformação de escola para Centro de Ensino. Assim foi criado o Centro de Ensino Especial de Deficientes Visuais - CEEDV (PPP CEEDV, 2018).

Por se tratar de estabelecimento especializado no atendimento de pessoas com deficiência visual, o CEEDV possui uma estrutura que visa:

Proporcionar à pessoa com deficiência visual e surdocega, inclusive ao estudante incluído, atendimento pedagógico em seu desenvolvimento sócio afetivo, físico e intelectual, mediante procedimentos didáticos e estratégias metodológicas adequadas para sua inclusão no ensino regular, às suas necessidades, desenvolvendo competências e habilidades na formação pessoal, social, orientação profissional e conhecimento de mundo, segundo as leis vigentes (PPP CEEDV, 2018).

Para exercer estas atividades o CEEDV conta com infraestrutura para apoiar o atendimento aos professores itinerantes através de suas salas de recursos, onde é possível elaborar, traduzir e/ou adaptar e transcrever materiais solicitados por estes professores (PPP CEEDV, 2018).

Em sua estrutura constam, também, um Núcleo de Produção Braille/Ampliado, um Núcleo de Convivência e um Núcleo de Apoio Pedagógico. No primeiro existem digitalizadores, adaptadores, transcritores e revisores. No PPP do CEEDV podemos entender melhor essas funções como: "Digitalizadores: São os servidores responsáveis em preparar, através da digitalização, os materiais didático-pedagógicos, solicitados pelos professores itinerantes onde devem ser observadas e levadas em consideração às especificidades de cada material, para as seguintes etapas: Adaptação e Transcrição. Adaptadores: São os servidores da Carreira Magistério Público do DF, cargo de professor, com habilitação, preferencialmente em Pedagogia e nas demais áreas de 
conhecimento, ou seja, Exatas, Humanas, Artes e Linguagens e que são responsáveis pela análise do material e adaptação em relevo de acordo com as especificidades, usando as Normas Técnicas da Comissão Brasileira de Braille-CBB. Transcritores: São os servidores da Carreira Magistério Público do DF, Cargo de professor, com habilitação, preferencialmente em Pedagogia e nas demais áreas de conhecimento, ou seja, Exatas, Humanas, Artes e Linguagens e que são responsáveis pela transcrição do material utilizando a simbologia Braille por meio do programa Braille Fácil e, ainda, de acordo com as Normas Técnicas de Transcrição de Textos para Língua Portuguesa e ainda o Código Matemático Unificado e a grafia Braille de Química. Revisor: Revisar o material em Braille (PPP CEEDV, 2018).”

Além de prover as necessidades de conteúdo e aprendizagem o CEEDV tem como norte a função precípua de capacitar seus alunos, construindo conhecimentos dinâmicos que garantam cidadania e autonomia para interação com o mundo (PPP CEEDV, 2018).

Em cumprimento à Lei de Inclusão No 13. 146, de 6 de julho 2015 (Estatuto da Pessoa com Deficiência, 2015), o Distrito Federal distribui os alunos com Deficiência e/ou TGD/TEA (Transtorno Global do Desenvolvimento / Transtorno do Espectro Autista) em Classes Comuns Inclusivas, de Integração Inversa, Classes Especiais, Classes Especiais Interventivas, EJA Interventivas, Classes Bilíngues, Classes Bilíngues Mediadas, Classes Bilíngues Diferenciadas mas, condiciona as referidas matrículas à existência de vaga no ano indicado no ato da inscrição, bem como à existência de serviço de apoio na UE pretendida, devendo estar identificado no sistema i-Educar Módulo Escola.

A escola classe onde a pesquisa foi realizada, possui uma sala de recursos com pelo menos dois educadores que dominam o sistema Braille e a técnica do Soroban. Há também materiais de apoio para os alunos com deficiência visual que recebem o atendimento necessário, geralmente no contra turno. Além dos profissionais da sala de recursos, há uma educadora itinerante que também desenvolve o trabalho com os alunos com deficiência da escola pesquisada e das escolas da região. 


\section{CAPÍTULO II - CONSIDERAÇÕES SOBRE O PROGRAMA EDUCADOR SOCIAL VOLUNTÁRIO}

Consta nas Orientações Pedagógicas para a Educação Especial do GDF que o acompanhamento individualizado do processo educativo dos estudantes com deficiência deve ser feito pelos educadores que atuam direta e indiretamente nas instituições educacionais onde os estudantes frequentam (SEEDF, Educação Especial, 2010).

Em 2010 este mesmo documento já falava sobre o apoio às instituições educacionais e aos professores do ensino regular em relação à inclusão escolar de alunos da educação especial. Citava que uma das formas de apoiar as demais instituições da rede pública de ensino do Distrito Federal no processo de inclusão educacional era a coordenação do Centro de Educação Especial em conjunto com a unidade de gestão central de Educação Especial e a Escola para Aperfeiçoamento dos Profissionais da Educação - EAPE, para "a realização da formação continuada dos professores da instituição educacional comum, de trocas de experiências entre professores da instituição educacional comum e da especial a fim de atender as demandas locais das Diretorias Regionais de Ensino" (SEEDF, Educação Especial, 2010).

Para apoiar estes educadores o GDF optou em instituir o Programa Educador Social Voluntário (ESV) que é uma ação voluntária na forma da Lei n ${ }^{\circ}$ 9.608/1998, portanto não gera vínculo empregatício nem obrigação de natureza trabalhista, "com o objetivo de estimular e fomentar ações voluntárias de cidadania e envolvimento comunitário" conforme Decreto $\mathrm{N}^{\mathrm{o}} 37.010 / 2015$. No texto deste decreto também fica definido que "serviço voluntário social: prestado por pessoa física da comunidade, que tenha objetivos cívicos e de promoção e exercício dos direitos humanos, culturais, recreativos ou assistenciais, nas áreas de saúde, educação, esporte, lazer, cultura, meio ambiente, assistência e defesa social e jurídica, dentre outros". Assim, começa-se construir a estrutura do que viria a ser o Programa Educador Social Voluntário. Para elaboração deste capítulo foram observadas as portarias de criação do Programa Educador Social Voluntário de 2014 a 2019. 
O Programa Educador Social Voluntário foi criado para auxiliar as escolas que atendem alunos em tempo integral, com intuito de dar suporte às atividades da educação integral, e as escolas de ensino regular recebem alunos da educação especial e ofertam atendimento educacional especializado.

Até a seleção de 2018, os responsáveis pela seleção dos candidatos desse programa são as de cada região administrativa, que formarão uma comissão avaliadora que deverá ser composta por no mínimo 3 (três) servidores da Coordenação Regional de Ensino (CRE), contando com suplentes. Já no ano de 2019 as inscrições e seleções são feitas diretamente na escola em que o candidato deseja atuar.

A primeira versão do Programa Educador Social Voluntário foi publicada na Portaria $\mathrm{N}^{\mathrm{o}}$ 43, de 27 de fevereiro de 2014, e não existe registro de quantidade de vagas disponibilizadas pois dependia de uma reserva orçamentária e financeira de cada CRE. O programa já visava na seleção de candidatos a preferência por universitários com formação específica nas áreas de desenvolvimento das atividades (GDF ESV, 2014) e contemplava:

I - Preferencialmente universitários de formação específica nas áreas de desenvolvimento das atividades; II - Estudantes da Educação de Jovens e Adultos - EJA; III - Estudantes do Ensino Médio; IV - Pessoas da comunidade com habilidades nas seguintes áreas: cultural, artística, desportiva, ambiental, de culinária, de serviços gerais e nas voltadas para a prática de atividades físicas, entre outras, podendo desempenhar a função de acordo com suas competências, saberes e habilidades (GDF ESV, 2014).

A medida que o programa foi sendo atualizado ao longo dos anos, a seleção de candidatos passou a abranger outras categorias conforme o Quadro 03 e apresentar novas exigências.

Quadro 03 - Características dos candidatos por ano.

\begin{tabular}{|l|l|l|l|l|l|l|}
\hline Característica & 2014 & 2015 & 2016 & 2017 & 2018 & 2019 \\
\hline Universitários de formação específica & $\mathrm{X}$ & $\mathrm{X}$ & $\mathrm{X}$ & $\mathrm{X}$ & $\mathrm{X}$ & $\mathrm{X}$ \\
\hline Estudantes da EJA & $\mathrm{X}$ & $\mathrm{X}$ & $\mathrm{X}$ & $\mathrm{X}$ & $\mathrm{X}$ & $\mathrm{X}$ \\
\hline Estudantes do Ensino Médio & $\mathrm{X}$ & $\mathrm{X}$ & $\mathrm{X}$ & $\mathrm{X}$ & $\mathrm{X}$ & $\mathrm{X}$ \\
\hline
\end{tabular}




\begin{tabular}{|l|l|l|l|l|l|l|}
\hline $\begin{array}{l}\text { Pessoas habilidosas da comunidade (houve } \\
\text { acréscimo de habilidades em 2019) }\end{array}$ & $\mathrm{X}$ & $\mathrm{X}$ & $\mathrm{X}$ & $\mathrm{X}$ & $\mathrm{X}$ & $\mathrm{X}$ \\
\hline $\begin{array}{l}\text { Pessoas com experiência comprovada em } \\
\text { Educação Especial e Saúde }\end{array}$ & & $\mathrm{X}$ & $\mathrm{X}$ & $\mathrm{X}$ & $\mathrm{X}$ & $\mathrm{X}$ \\
\hline $\begin{array}{l}\text { Exigência de comprovação de experiência } \\
\text { citadas acima }\end{array}$ & & & $\mathrm{X}$ & $\mathrm{X}$ & $\mathrm{X}$ & $\mathrm{X}$ \\
\hline
\end{tabular}

Fonte: Elaboração da autora (2019).

No ano de 2014 não houve descrição clara das atividades realizadas pelo ESV na escola que fosse apoiar, a portaria resumia-se a descrever o processo seletivo dos candidatos (GDF ESV, 2014). A portaria seguinte do ano de 2015 já considerou as atividades dos ESV e também atribuiu algumas responsabilidades no processo. Para o suporte ao atendimento educacional especializado definiu a responsabilidade de capacitar o ESV ao Profissional da Sala de Recursos da Unidade Escola. Ao mesmo profissional coube a responsabilidade de orientar e supervisionar as seguintes atividades executadas pelo ESV (GDF, 2014): "atividades de acompanhamento, higiene pessoal e incentivo de estudantes, bem como de outras atividades voltadas para a área de Educação Especial, quais sejam: auxiliar os alunos nos horários das refeições, no uso do banheiro, na escovação dentária, no banho e troca de fraldas, na hora de se vestirem e se calçarem, no momento do parque, em atividades no pátio escolar, na educação física, em passeios, ou seja, deverão estar presentes nas atividades diárias, autônomas e sociais que os alunos com deficiência realizarão dentro e, quando necessário, fora do contexto escolar. Sob a supervisão do professor, realizará o controle da baba e de postura do aluno, como ajudá-lo no sentar-se/levantar-se na/ da cadeira de rodas, carteira escolar, colchonete, vaso sanitário, brinquedos no parque; deverá empurrar a cadeira de rodas do estudante que dela fizer uso, para todos os espaços escolares a que ele necessitar ir, como também, em outros, fora do ambiente escolar; auxiliar na organização dos materiais pedagógicos; informar ao(à) professor(a), para registro, as observações relevantes relacionadas ao(à) estudante; acompanhar e auxiliar o(a) estudante durante as atividades pedagógicas para aquisição de condutas adaptativas em sala de aula e extraclasse de acordo com as orientações do(a) professor(a); apoiar o(a) estudante que apresente momentos de descontrole comportamental, observando os sinais de angústia e ansiedade prévios, conhecendo as condições que, potencialmente, o desestruturam, buscando prevenir crises, 
intervir o quanto antes e acompanhar o(a) estudante com alteração no comportamento adaptativo a outros espaços e atividades pedagógicas, sob orientação do professor, da equipe escolar e/ou dos serviços de apoio; estimular/favorecer a comunicação e a interação social do(a) estudante com seus(suas) colegas e demais pessoas; executar outras ações similares que se fizerem necessárias com o mesmo grau de complexidade e responsabilidade (GDF, 2014)".

Em especial ressalto a penúltima atribuição citada que é a de "estimular/favorecer a comunicação e a interação social do(a) estudante com seus(suas) colegas e demais pessoas" (GDF, 2014) pois está em consonância com a Lei de Brasileira de Inclusão da Pessoa com Deficiência (Estatuto da Pessoa com Deficiência, 2015) e o foco desta pesquisa.

Ainda sobre as responsabilidades na capacitação do candidato, quando o suporte fosse relativo às atividades de Educação Integral, ficou estabelecido que o Supervisor Pedagógico da Unidade Escolar seria o responsável pela orientação e supervisão do ESV (GDF ESV, 2015).

Os anexos da última portaria de 2019, são enfáticos a respeito dos direitos do ESV em relação capacitação e orientação que devem receber.

CLÁUSULA NONA - São DIREITOS do voluntário: receber capacitação e/ou orientações para exercer adequadamente suas funções; encaminhar sugestões e/ou reclamações ao responsável pelo corpo de voluntários do órgão, visando o aperfeiçoamento da prestação dos serviços; ter acesso às informações institucionais para o bom desempenho de suas atividades, nos termos da Lei no 4. 990/2012; ser apresentado ao corpo funcional e ao público beneficiário dos serviços prestados; ter a divulgação periódica dos resultados alcançados no exercício de suas atividades.

Em momento algum as portarias estudadas foram específicas em relação aos estudantes com deficiência visual, mas nas atividades previstas para auxílio do ESV a portaria de 2015 já descreve que o mesmo deve estar presente em todas as atividades diárias, autônomas e sociais que os alunos com deficiência realizarão no ambiente escolar devendo assim ser considerado como um profissional de apoio escolar segundo o inciso XIII, alínea e), Art. $3^{\circ}$ da Lei de Brasileira de Inclusão da Pessoa com Deficiência (Estatuto da Pessoa com Deficiência, 2015).

Em 2017, a portaria incluiu a atribuição de auxiliar na organização dos materiais pedagógicos e a necessidade de informação ao professor das observações relevantes ao 
estudante (GDF ESV, 2017). Estas tarefas embora simples, indicam a importância do ESV uma vez que o mesmo estará dedicado a observar e acompanhar as atividades dos alunos com deficiência com proximidade e tempo exclusivo maiores até que o próprio professor responsável, podendo assim obter informações muito úteis ao planejamento pedagógico das atividades para aquele aluno.

A portaria do Programa Educador Social Voluntário de 2018 contempla a inclusão do suporte em Unidades Escolares de Educação Infantil, suporte a estudantes indígenas, Núcleos de Ensino das Unidades de Internação Socioeducativas, atribuindo a responsabilidade de capacitação, orientação e supervisão da Equipe Gestora, Supervisor Pedagógico ou da Coordenação Pedagógica da unidade escolar. O apoio e suporte pelo ESV na Escola Meninos e Meninas do Parque foi incluído na portaria de 2019.

Os critérios de seleção do programa ESV contemplam uma pontuação formada pelos atributos evidenciados pelo candidato e por uma entrevista (GDF ESV, 2019). Estes critérios estão descritos na Tabela 01 e na Tabela 02, anexos da portaria do programa ESV.

Tabela 01 - Anexo I - Dos critérios de seleção e classificação

\begin{tabular}{|c|c|c|}
\hline Item & Formação & Pontuação \\
\hline 01 & $\begin{array}{c}\text { Formação } \\
\text { Nível Superior completo }\end{array}$ & 10 pontos \\
\hline 02 & $\begin{array}{c}\text { Formação } \\
\text { Nível Superior em curso }\end{array}$ & 6 pontos \\
\hline 03 & $\begin{array}{l}\text { Ensino Médio EJA } 3^{\circ} \text { segmento e curso técnico de nível médio da } \\
\text { Educação Profissional completo. }\end{array}$ & 5 pontos \\
\hline 04 & $\begin{array}{c}\text { Ensino Médio EJA } 3^{\circ} \text { segmento e curso técnico de nível médio da } \\
\text { Educação Profissional em curso. }\end{array}$ & 3 pontos \\
\hline 05 & \begin{tabular}{|} 
Pessoas da Comunidade com habilidades nas seguintes \\
áreas: Cultural, artística, desportiva, ambiental, de culinária, \\
tecnologia, científica, nutrição, de serviços Gerais (exceto limpeza \\
e vigilância) e nas voltadas para a prática de atividades em \\
laboratórios de física, química e biologia, educação física, \\
informática, audiovisual, rádio, cineclubes, empreendedora, \\
sustentável, entre outras, podendo desempenhar a função de acordo \\
com as competências saberes e habilidades;
\end{tabular} & 5 pontos \\
\hline Item & \begin{tabular}{|l|} 
Critério I \\
\end{tabular} & Pontuação \\
\hline 06 & $\begin{array}{c}\text { Experiência em atividade voluntária na rede pública de } \\
\text { Ensino (Comprovada por declaração da Unidade Escola onde atua } \\
\text { ou atuou). }\end{array}$ & $\begin{array}{l}5 \text { pontos, acrescidos de } 01(\mathrm{um}) \\
\text { ponto por ano atuado em atividade } \\
\text { voluntária na rede pública de } \\
\text { ensino, efetivamente. }\end{array}$ \\
\hline 07 & Experiência em atividade voluntária nos termos da Lei no 9. & 5 pontos \\
\hline
\end{tabular}




\begin{tabular}{|c|c|c|}
\hline & $\begin{array}{c}608 / 1998 \text { em outras instituições, comprovada por } \\
\text { declaração. }\end{array}$ & \\
\hline 08 & $\begin{array}{c}\text { Experiência relacionada à atividade a ser desenvolvida, mediante } \\
\text { apresentação de documento comprobatório. }\end{array}$ & 5 pontos \\
\hline 09 & $\begin{array}{c}\text { Inscrição em Programa Social, Distrital ou Federal, como Bolsa } \\
\text { Família, Bolsa PROJOVEM, PROUNI, FIES, entre outros; e/ou } \\
\text { mulheres abrigadas em organização do estado e/ou com medida } \\
\text { protetiva. }\end{array}$ & Pontuação \\
\hline Item & Critério II & 30 pontos \\
\hline 10 & Entrevista & \\
\hline
\end{tabular}

Fonte: Anexos ESV (GDF ESV, 2019)

O processo seletivo do Educador Social Voluntário é claro e a escolha do candidato é meritocrático, por prova de títulos, como vimos acima. Um candidato com formação do ensino superior já garante 10 pontos, candidato cursando o ensino superior, 6 ponto;

Tabela 02 - Anexo II - Pontuação da Entrevista

\begin{tabular}{|l|l|}
\hline Apresentação pessoal (o que e como o candidato fala & 0,0 pontos se for ruim \\
sobre si) & 2,0 pontos se for regular \\
& 4,0 pontos se for boa \\
& 8,0 pontos se for excelente \\
\hline Demonstração de conhecimento e interesse (o candidato & 0,0 pontos se for ruim \\
parece ter domínio da área em que se propõe a atuar?) & 2,0 pontos se for regular \\
& 4,0 pontos se for boa \\
& 8,0 pontos se for excelente \\
\hline Comunicação e desenvoltura (o candidato consegue se & 0,0 pontos se for ruim \\
expressar adequadamente para o desempenho da & 2,0 pontos se for regular \\
função?) & 4,0 pontos se for boa \\
\hline Disponibilidade de tempo (os horários de que o & 8,0 pontos se for excelente \\
voluntário dispõe para atuar são adequados às & De 0,0 a 6,0 pontos de acordo com a realidade da UE. \\
necessidades da Unidade Escolar?) & \\
\hline Total & 30,0 pontos \\
\hline
\end{tabular}

Caso haja empate, terá preferência o candidato que, na seguinte ordem:

1. Idade mais elevada, conforme Estatuto do Idoso, art. 27, Lei No 10. 741/2003.

2. Possuir maior nota na Entrevista;

3. Possuir maior pontuação referente à formação;

4. Ser beneficiário de Programa Social.

Fonte: Anexos ESV (GDF ESV, 2019)

De acordo com o estipulado no edital do programa Educador Social Voluntário, espera-se que o perfil do candidato seja de pessoa com experiência na atuação com deficientes visuais, sejam eles cegos ou com baixa visão. Gradativamente o edital vai adicionando, ao 
perfil esperado, pessoas com outras características afins ao trabalho que será realizado, ficando cada vez mais raso devido o distanciamento entre o que é pedido de experiência no edital, com a necessidade do atendimento que a escola espera e como está sendo na prática.

Os estudantes com deficiência visual atendidos nas séries iniciais das escolas regulares possuem necessidades muito específicas que demandam recursos e serviços acessíveis. Os professores dessas salas podem, ou não, ser especializados no atendimento educacional específico, mas seu planejamento deve contemplar todos os alunos da classe, o que inclui os alunos cegos e os com baixa visão.

A sala de aula com quantidade de alunos reduzida já visa facilitar o planejamento de tarefas que possam incluir os alunos com deficiência pertencentes à turma, permitindo que a professor os dê atendimento mais individualizado, uma vez que suas necessidades são diferentes dos demais alunos. Contudo, nem sempre o professor consegue fornecer este atendimento, tendo também que apoiar nas necessidades não didáticas que estes alunos possuem. Segundo Manzini, um professor bem preparado consegue dar um melhor suporte para alunos com deficiência e cria condições de desenvolvimento para esse aluno:

Um professor bem preparado é aquele que tem claro e definido, na prática e na teoria, como conduzir o processo de ensino, como explicar a aprendizagem, como avaliar e reformular seu plano de ensino frente ao planejamento preestabelecido. Não se tratar, portanto, de adequar o currículo, mas como criar condições para que o seu aluno consiga tomar posse do currículo que ele precisa. (MANZINI, 2007, p. 82)

É neste momento que o Educador Social Voluntário, selecionado pela Coordenação Regional de Ensino (CRE) passa a disposição da escola apoiada. Sua missão será a de atuar como ferramenta de apoio ao professor, propiciando um ambiente propício à inclusão dos alunos com deficiência. 


\section{CAPÍTULO III. PROCEDIMENTOS METODOLÓGICOS}

$\mathrm{O}$ interesse pela pesquisa teve início a partir do estágio obrigatório em uma escola pública do DF, onde tive a oportunidade de participar da prática pedagógica com um aluno cego do $4^{\circ}$ ano, dois alunos cegos e um com baixa visão do $5^{\circ}$ ano. Foram 210 horas de observação participante, registradas em diário de campo para o estágio. Após cumprir as horas exigidas deste estágio, continuei com a observação e prática pedagógica em um acompanhamento voluntário nas mesmas turmas. Através desse acompanhamento e da prática exercida, alguns aspectos me chamaram a atenção, uma vez que aquela era uma escola pólo para deficientes visuais da região. Escola pólo, por ser mais preparada e ter mais recursos para o atendimento a crianças com deficiência visual na região administrativa do Paranoá e entorno. A observação considerou a estrutura da escola, o atendimento da sala de recursos, a dinâmica de estudos em sala, os professores e, o que mais me chamou a atenção, o atendimento dos chamados "monitores" ou educadores sociais voluntários.

A motivação da escolha do tema da pesquisa considerou a necessidade de compreender o processo de atuação do Educador Social Voluntário (ESV) e suas contribuições para a inclusão escolar de alunos com deficiência visual em salas de aula regulares. Questões foram levantadas devido a dúvidas relativas à atuação e experiência destes ESV; para saná-las, foi necessário conhecer a legislação nacional e distrital que garante o direito à educação para as pessoas com deficiência e, mais especificamente, os marcos legais que regulamentam a atuação do ESV no Distrito Federal. A análise documental também foi realizada com intuito de ampliar o conhecimento do projeto político pedagógico da escola pesquisada e do Centro de Ensino Especial de Deficientes Visuais CEEDV).

A escola escolhida é polo de acolhimento de alunos com deficiência visual e baixa visão. Nessa escola, três professores (sendo dois atuantes na sala de recursos em período integral e uma itinerante) dominam o Sistema Braille e auxiliam no atendimento e suporte dos seis alunos com deficiência visual (três cegos e três baixa visão) que frequentam a unidade escolar. 
A pesquisa consiste em uma pesquisa qualitativa, que utilizou a aplicação de questionários e a realização de entrevistas semiestruturadas com professores e educadores sociais voluntários que atuam com estudantes com deficiência visual. A entrevista, de acordo com Cruz Neto (1994), é um procedimento em que, através da fala dos atores sociais, o pesquisador busca informações.

Foi entregue pela pesquisadora um Termo de Consentimento - Apêndices A, B e C, assinado pelos envolvidos na pesquisa, como forma de autorização do uso de informações para a pesquisa, bem como de questionários de perfil dos entrevistados - Apêndice D. A autora da pesquisa teve como objetivo entrevistar professores da sala de recursos, da sala regular e educadores sociais que faziam parte do atendimento aos alunos com deficiência visual. Porém a professora da sala de recursos não teve interesse em participar, contabilizando assim a contribuição de cinco entrevistados, sendo eles:

- Uma professora itinerante, que atua no suporte da sala de recursos, conhece e acompanha todos os seis alunos deficientes visuais da escola e outros com demais deficiências;

- Duas professoras da sala de aula regular que atuam nas classes dos alunos acompanhados e

- Dois Educadores Sociais Voluntários que acompanham deficientes visuais.

As entrevistas foram feitas presencialmente na biblioteca da escola e com recursos de gravação áudio por smartphone e também por aplicativos de mensagens por áudios e vídeos. Para preservar a identidade dos entrevistados, no quadro abaixo contaremos com nomes fictícios:

Quadro 01: Tempo e duração das entrevistas e nomes fictícios dos participantes da entrevista

\begin{tabular}{|l|l|l|}
\hline Sujeitos & Nome fictício & Tempo de duração \\
\hline Professora da sala comum & $4^{\circ}$ ano - Lia & $00: 15: 34$ \\
\hline Professora da sala comum & $5^{\circ}$ ano - Maria & $00: 05: 13$ \\
\hline Professora sala de Recursos / itinerante & Ana & $00: 04: 23$ \\
\hline
\end{tabular}




\begin{tabular}{|l|l|l|}
\hline Educador Social Voluntário & John & $00: 05: 04$ \\
\hline Educadora Social Voluntária & Paula & $00: 03: 50$ \\
\hline
\end{tabular}

Uma vez definidos os sujeitos da pesquisa e o método de coleta dos dados, foi necessário estabelecer o perfil dos educadores que atuam no ensino de alunos cegos e com baixa visão naquela escola, a fim de identificar as experiências de cada um e a formação que eles possuem. Em seguida, analisou-se a ótica dos entrevistados sobre como se dá a inclusão escolar e o atendimento educacional especializado dos alunos com deficiência visual na escola pesquisada. Enfim, foi descrito como se dá a atuação dos educadores sociais voluntários na inclusão escolar de alunos com deficiência visual, concluindo, então, com os desafios encontrados no processo de inclusão escolar. 


\section{CAPÍTULO IV - ANÁLISE DE DADOS}

Neste capítulo será apresentado o perfil, a experiência e a formação dos professores de sala comum, da professora itinerante da sala de recursos e também dos Educadores Sociais Voluntários, bem como as ações para oferta do atendimento educacional especializado aos alunos deficientes visuais. Os dados foram reunidos através de entrevista semiestruturada, de questionário de perfil e de análise documental.

\subsection{Perfil dos participantes da pesquisa e formação específica na área da deficiência visual}

Lia, sexo feminino, tem 31 anos de idade. Formada em Pedagogia pela Universidade Estadual de Goiás (UEG), concluiu sua graduação no ano de 2008 e realizou pós graduação na área de Orientação Educacional no ano de 2011. Participa de formação continuada pela SEEDF e demais instituições. Realizou diversas formações continuadas nas temáticas de ensino inclusivo, alfabetização e letramento, psicogênese, desenvolvimento cognitivo infantil e outros. Ainda não realizou curso em uma área específica de inclusão e deficiência visual, por causa da dificuldade de adaptação e falta de suporte, mas pretende fazer. Atua como educadora há 12 anos, sendo 2 na área da coordenação. Está na SEEDF há 7 anos atuando como professora na mesma instituição de ensino. Nunca havia trabalhado com alunos com deficiência visual, mas aceitou a pedido da gestão da escola.

Maria, sexo feminino, tem 45 anos de idade. Formou-se em Geografia em 1999 e em 2008 formou-se pedagoga. Não possui pós graduação. Participa de cursos de formação continuada pela SEEDF e demais instituições de ensino. Concluiu vários cursos, incluindo alfabetização e inclusão. Exerce a função de educadora há 8 anos, sendo 4 deles na área de ensino de Geografia e os demais em Pedagogia. Está na instituição de ensino há 3 anos.

Ana, sexo feminino, tem 43 anos. Formada em Pedagogia pela UnB, concluiu sua graduação no ano de 1996 e fez pós graduação na área de Psicopedagogia em educação de 
surdos no ano de 1999; após, concluiu mestrado em surdocegueira na mesma instituição. Participa de cursos de formação continuada pela SEEDF e demais instituições. Concluiu vários cursos na área de inclusão, incluindo a deficiência visual, auditiva, TEA e outros. Atua como educadora há 21 anos e na SEEDF há 17 anos na área de inclusão na mesma instituição. $\mathrm{Na}$ época em que ela se graduou na UnB era possível a habilitação do curso em áreas específicas da educação, onde direcionou o curso para a educação especial. Ter um irmão “especial" foi o que a levou para a área da inclusão. No ano de 2007, iniciou sua carreira no AEE, onde ainda atua, sendo hoje, professora itinerante na área da deficiência visual. Dentre as formações continuadas estão os cursos: braille, soroban, Deficiência visual para início de escolarização, AEE de deficiente visual, Matemática braille, Orientação e Mobilidade

John, sexo masculino, tem 27 anos de idade. Concluiu ensino médio pelo EJA no ano de 2010. Primeira experiência na área de educação foi exercendo a função de ESV. Não possui cursos e formação na área de educação. Está na função de ESV acompanhando aluno com deficiência visual em 2 instituições de ensino pertencentes a mesma CRE.

Paula, sexo feminino, tem 21 anos de idade. Concluiu ensino médio no ano de 2015. Não possui cursos e formação na área de educação. Está na função de ESV acompanhando aluno com deficiência visual pela primeira vez.

O perfil relativo à idade dos educadores estudados, bem como sua escolaridade e cursos de formação específica apresenta-se conforme o Gráfico 03.

Gráfico 03 - Idade, escolaridade, formação específica e tempo de educador dos entrevistados. 


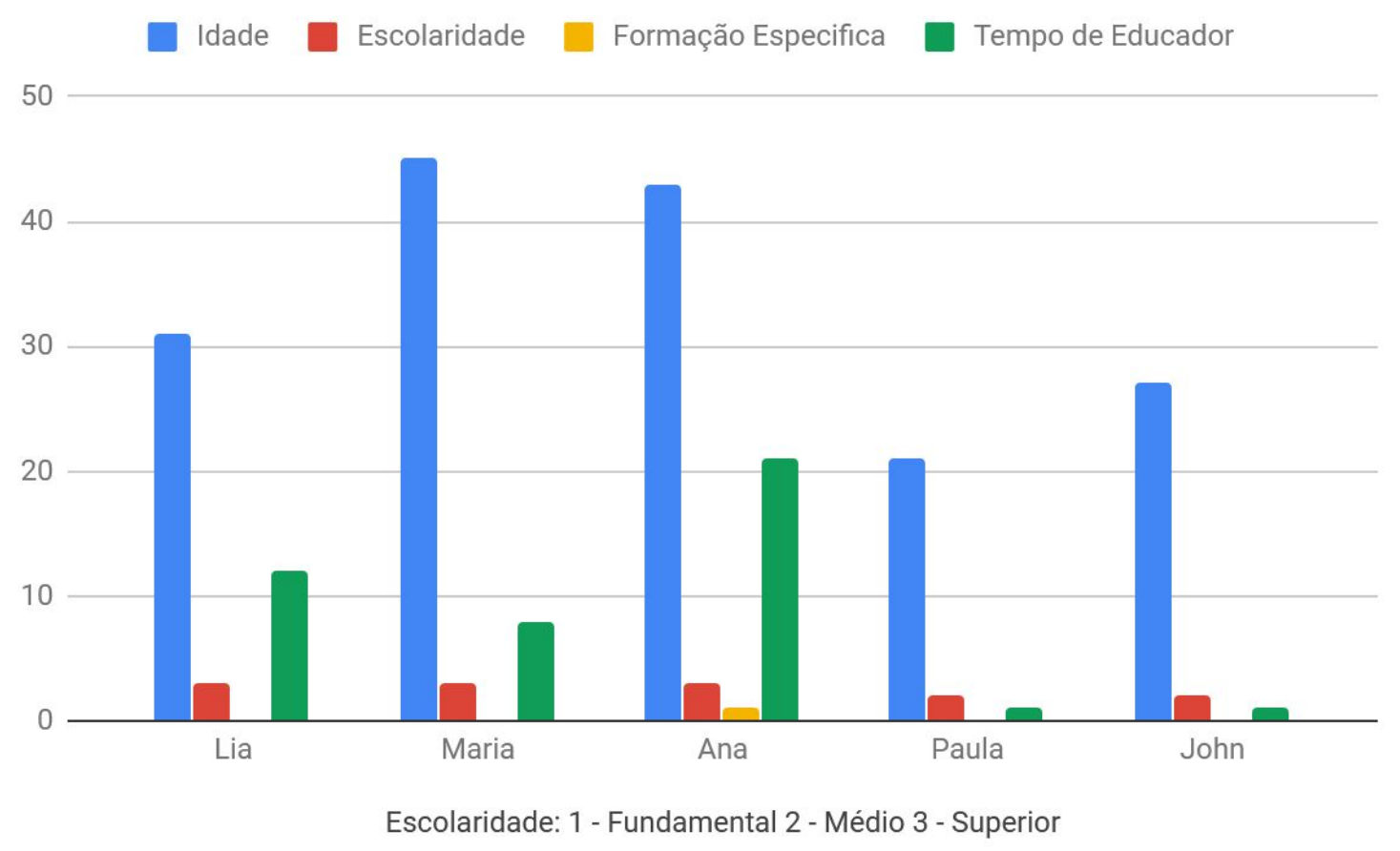

Fonte: Elaboração da autora (2019).

Foi constatado que apenas a professora itinerante possui formação na área específica de deficiência visual. Uma das professoras demonstrou interesse na temática da deficiência visual, porém ainda não encontrou recursos para a esse aperfeiçoamento. $\mathrm{O}$ interesse de formação em áreas específicas está se dando através da experiência vivida, primeiramente o professor se depara com um aluno deficiente visual na sala e, a partir da dificuldade enfrentada, acompanha o desejo de especialização. Isso acontece não por falta de interesse dele, mas por falta de conhecimento específico para cada deficiência.

O não conhecimento, pelo professor e profissionais da educação em sala de aula, sobre a deficiência visual, torna tudo mais difícil, pois muitos alunos podem manifestar comportamentos diferenciados como os movimentos estereotipados, levando o professor fazer uma adequação voltada a outra deficiência, dificultando, assim, a oferta do recurso acessível ao estudante. 


\subsection{A inclusão escolar dos alunos com deficiência visual na escola pesquisada}

No ambiente escolar foi possível notar a carência de acessibilidade física na escola. A escola possui pilastras em boa parte do ambiente de passagens, piso irregular e muitos lugares com pequenas escadas. No Projeto Político Pedagógico (PPP) da escola pesquisada, há projetos para inclusão de alunos com deficiência, porém nada voltado especificamente aos deficientes visuais e também não foi notado para outros tipos de deficiência, por mais que tenham alunos com outras deficiências na escola pesquisada.

Uma parte do questionário aplicado tentava identificar as percepções dos entrevistados sobre o modo como os alunos com deficiência visual eram incluídos no ensino regular. Também foi questionado se julgavam ser eficiente esta inclusão no ambiente da escola, solicitando-os a enumerar pontos positivos e negativos.

As respostas obtidas foram, na sua maioria, a favor da inclusão dos alunos com deficiência visual em salas regulares, mas todos colocaram respaldos durante suas respostas. Normalmente eram observações acerca das peculiaridades em relação ao grau da deficiência apresentada. Quando se tratava de um aluno com baixa visão as respostas indicavam maior adesão, pois os professores tinham, ao seu ver, mais facilidade de adequação. Quando se travava de cegos, as ressalvas vinham à tona, muitas vezes devido à falta de formação para atendê-los. Assim diz Ana:

Sobre a inclusão escolar, sou favorável para o aluno com baixa visão, pois não há nenhuma dificuldade do aluno, se as adequações ocorrerem de acordo com a avaliação funcional da visão. Com relação ao aluno cego, acredito que, primeiro é necessário o aprendizado da alfabetização do braille e do Soroban, para que depois seja feita a inclusão dele, no terceiro ou quarto ano do ensino fundamental. Fica difícil fazer tudo isso na sala de recursos ou na sala de inclusão regular do aluno, pois o tempo é muito pequeno. O aluno acaba perdendo em aprendizado se comparado ao aluno vidente.

Lia ainda é mais enfática ao concordar com a inclusão, quando leva em consideração o efeito social que imprime na criança: "Positivo, acho que a socialização é positiva. Meu aluno por exemplo, brinca no parquinho como se ele enxergasse o parquinho, ele sobe na casinha, desce no escorregador, ele empurra os meninos no balanço e faz tudo isso mesmo 
que eu fique aflita, preocupada em ele se machucar". A entrevistada deixa escapar o quanto o desenvolvimento da independência do aluno a impressiona: "Comento com minha família, sempre, sobre como ele é independente e anda pela escola toda. Ele sabe! Mesmo se não tiver ninguém para levá-lo para beber água. Ele sabe! E vai sozinho! Nesse sentido acho a inclusão válida, nessa parte de socialização".

"A aprendizagem em si, depende muito da criança, do professor e de todo um sistema", ressalta Lia em suas respostas. Ao comentar o lado negativo, Lia diz: "O negativo é como já disse, acho que eles ficam a "beira margem", a margem de tudo que ocorre no processo de ensino e aprendizagem, porque não têm aquela 'coisa' voltada pra ele". Lia também reconhece a importância de uma formação específica para atender os alunos com deficiência, ela têm ciência de que uma qualificação implica, consequentemente, em um melhor atendimento ao aluno. "De repente, se eu tivesse uma formação na área eu faria muito melhor pra ele, bem melhor, talvez ele não teria problemas como ele teve na troca ortográfica, ele não teria dificuldade em matemática, não teria que decorar tabuada por eu não saber Soroban. Eu via o Soroban na escola, eu via a máquina braille aqui na escola, apenas isso".

Maria, por sua vez, discorda da inclusão no modo como está sendo feita. Sua impressão é que a inclusão não ocorre: "Eu percebo que não existe muito essa inclusão", diz Maria. Talvez esta reação se dê pelo fato de Maria não se considerar preparada para receber um aluno com deficiência visual ou por não receber o apoio especializado que julga ser necessário para os alunos. É enfática ao dizer que não espera "pegar" outra turma com deficientes visuais, mas atribui ao fato de ser professora do serviço temporário, o motivo de não ter opção de escolha.

Maria, que não têm especialização, confiava que o monitor teria a experiência necessária para atuar com os alunos com deficiência visual. Ela é direta ao falar que os ESV que atendem sua turma são despreparados: "pensei que os monitores saberiam lidar, mas também estão sem saber o que fazer e os meninos ficam perdidos, assim como a gente". Contudo ela percebe que a socialização é a parte "boa" do processo, pois permite o convívio dos alunos com mais pessoas despertando a "vontade de fazer alguma coisa".

John, educador social voluntário, não apresentou opinião sobre o que implica, para o aluno com deficiência visual, a inclusão em uma escola regular. Suas respostas ficaram 
restritas ao modo como que foi selecionado. Para ele o seu papel não é relacionado a inclusão e não tem expressão social: "somos tratados como um monitor apenas, que está ali para acompanhar", diz John. Contudo demonstra o interesse em aprender.

O conhecimento de Paula sobre seu papel na inclusão social dos alunos foi ainda mais superficial. As informações que possuía resumiam-se ao funcionamento do processo de seleção e como eram feitas as solicitações pela Regional de Ensino.

É necessário que o professor tenha uma formação continuada na área de inclusão, pois a partir da teoria e das experiências vividas ele formule práticas para um melhor atendimento aos alunos deficientes. Figueiredo considera a formação dos professores de forma que:

\footnotetext{
No percurso da inclusão, os professores irão ampliar e elaborar suas competências e habilidades a partir das experiências que já têm. A formação continuada considera a formulação de conhecimentos do professor, sua prática pedagógica, seu contexto social, sua história de vida, suas singularidades e os demais fatores que o conduziram a uma prática pedagógica acolhedora. (FIGUEIREDO, 2008, p. 144)
}

Observando a afirmação da autora, podemos entender a necessidade e importância desse estudo continuado, onde através dele e da vivência o professor também adquira mais conhecimentos entorno a temática que aplicará em sala de aula.

\subsection{O atendimento educacional especializado para os alunos com deficiência visual}

A comunicação entre professores, alunos e família é um dos principais elos para fortalecer a organização de uma escola inclusiva. Na escola pesquisada, o AEE se inicia pela anamnese (acolhimento, entrevista) com a família e a professora itinerante faz uma avaliação para conhecer o aluno, a família, o nível de aprendizagem desse aluno a fím de traçar o planejamento para ele. Assim, ela socializa o perfil desse aluno aos professores da sala de recursos e da sala de aula regular, para que os mesmos possam planejar as atividades e as adequações. "Conheço o aluno para traçar o planejamento. Após uma avaliação, inicio com as 
facilidades e dificuldades apresentadas pelo aluno. No AEE, trabalho de acordo com o laudo e a avaliação funcional da visão. Muitas vezes precisamos produzir o pré-braille e o pré-soroban" disse Ana.

É importante essa avaliação devido à complexidade de cada deficiência; seja a criança cega ou com baixa visão, os recursos variam de acordo com a experiência e a necessidade de estímulo. "Com alunos baixa visão, após a avaliação funcional da visão, realizo atividades de contrastes e treinamento de visão subnormal. Muitos apresentam outras comorbidades e se faz necessário trabalhar memória e outras atividades de percepção e discriminação", disse Ana.

O sistema de avaliação acontece diariamente, através da observação das atividades propostas na sala de recursos, que depois são enviadas ao professor da sala de aula regular. "Para a avaliação observo as respostas das atividades, algumas mantenho, outras sei que posso avançar e outras preciso retomar. Além do AEE, faço junto ao professor regente a adequação curricular e a avaliação também", explica Ana.

O conteúdo trabalhado na sala de recursos nem sempre acompanha o da sala de aula regular devido ter seu planejamento próprio, mas professores da sala de aula regular necessitam desse acompanhamento. Ana afirma que "o trabalho não pode ser estanque. Às vezes pode até ser diferenciado, pois o regente tem o conteúdo a ser trabalhado, mas a articulação entre os pares só ajuda o aluno deficiente visual e o êxito acontece”.

É necessário um professor especializado em deficiência visual, pois precisa estar sempre junto de seus alunos cegos e/ou baixa visão, para que assim, possam favorecer experiências auditivas, olfativas, táteis, dentre outras. Além de trabalhar também com a autonomia desses alunos através das atividades de vida diária, o professor deve orientar quanto à locomoção no ambiente escolar, treinar a escrita cursiva (para que pessoas com deficiência visual possam assinar documentos), ensinar a leitura e escrita Braille, o uso do Soroban e demais materiais de apoio e de tecnologia assistiva.

O apoio das salas de recursos e/ou AEE é favorável para despertar no aluno a autonomia no ambiente escolar e a interação com os demais alunos. A atuação do professor, que é o mediador no ambiente escolar, deve ser orientada para que haja uma verdadeira inclusão no ambiente escolar e que os alunos deficientes visuais recebam a mesma atenção e oportunidade de aprendizagem que os alunos videntes. 
O aluno que apresenta deficiência visual precisa encontrar um ambiente escolar adequado às suas necessidades educacionais especiais, assim como educadores aptos a compreendê-lo. Essas são condições essenciais na construção do vínculo em sala de aula, uma vez que as necessidades educacionais e o processo de desenvolvimento equivalem aos das crianças videntes. (VILLAS BOAS et al, 2012)

Este professor mediador é o personagem capaz de satisfazer a inquietação descrita por Zardo quando diz que "Desse modo, a pessoa com deficiência inquieta o saber instituído e coloca em questionamento os lugares que a sociedade construiu para ela" (ZARDO, 2012).

Às vezes, a falta de conhecimento sobre os materiais da sala de recursos podem atrasar atividades importantes para o aluno com deficiência. Lia diz: , mas descobri porque eu fui atrás, eu descobri porque falei que não tinha nada, aí que falaram que tinham e vieram me entregar livrinhos". Atividades de leitura são cruciais, estimulam as funções cognitivas e a criatividade, tanto do vidente quanto a pessoa cega.

O aluno de Lia, como exemplo, encontrou em um dos livros em braille uma oportunidade ímpar, pois tratava-se de um exemplar único transcrito somente em braille e que, consequentemente, somente ele poderia ler para a turma. Neste contexto, a sala de recursos propiciou que o aluno tomasse o seu lugar dentre os demais na classe inclusiva. Lia ressalta que não faz adaptação para as aulas do seu aluno, somente transcrição. Assim, todas as atividades que os demais alunos fazem, o aluno deficiente visual também realiza. O único problema é que a transcrição depende da sala de recursos, mas nem sempre é feito em tempo hábil.

Quanto ao uso do Soroban, o aluno tem que se dirigir à sala de recursos pois o mesmo não é disponibilizado para sala de aula devido a demanda. Em particular, Lia optou por utilizar a tabuada com o aluno deficiente visual. Esta decisão reduziu os problemas com matemática, não só do aluno cego, mas também de outros da sala. 


\subsection{A atuação dos educadores sociais na inclusão escolar de alunos com deficiência visual}

$\mathrm{Na}$ escola onde aconteceu a pesquisa, os educadores sociais voluntários entrevistados não possuíam formação na área da educação, tampouco na deficiência visual. Porém, ambos disseram que tinham interesse de atuar na área da educação e a contribuição financeira que na verdade é uma ajuda de custo para transporte e alimentação desses ESV, além da experiência foram o que os motivaram. "Sempre tive interesse na área da educação. E foi uma oportunidade que apareceu para uma renda extra e também para garantir uma experiência, já que eu não tinha nenhuma", disse Paula. "Sempre gostei de trabalhar com público em específico com crianças, como estava desempregado e não consegui nenhuma oportunidade de emprego, decidi ler o edital que fala sobre o educador social e foi quando eu resolvi atuar na escola. E também é um dinheiro a mais, além da experiência”, disse John.

Possivelmente por ser função do professor regente e a falta de experiência na área da educação, sem possuir formação na área de inclusão ou mesmo de deficiência visual, durante a observação, e por muitas vezes, os educadores sociais voluntários não conseguiam fazer com o que os alunos com deficiência visual acompanhassem as aulas.

Por vezes, os ESV não conseguiam decidir uma maneira simples de ajudar os alunos com deficiência visual na hora das atividades. Ficavam entre repassar o conteúdo oralmente e escreviam a resposta das atividades ou em fazer o aluno utilizar a máquina braille para copiar a matéria e ou apenas as respostas do que estava sendo passado no quadro. Dúvidas como esta seriam sanadas se o ESV tivesse recebido uma formação mínima para atender o tipo de deficiência apoiada. Um exemplo, seria definir que professora regular escolha a ação do ESV, sempre que for ministrar um conteúdo extenso, otimizando atividades ele possa realizar sozinho, como buscar a máquina braille ou livros previamente preparados na sala de recursos.

O ESV John foi claro quando disse: "Não temos reconhecimento como tal, somos tratados como um monitor apenas, que está ali para acompanhar. Mas eu queria ter a oportunidade de aprender mais em sala de aula, gostaria de ter um curso preparatório, algumas instruções antes de entrar dentro de sala, é bom né?”. Estas palavras indicam que ele 
tem interesse em se especializar, mas em outro momento, John também comenta que a especialização é muito cara e não condiz com o valor pago para o ESV.

Observando a fala de John, por muitas vezes o ESV não entendem que o "valor pago"é apenas uma ajuda de custo para que ele se alimente e chegue até o local de atuação. Percebe se que eles veem o serviço voluntário como um emprego, onde existe um salário pelo serviço.

Embora no edital esteja previsto que o ESV receberá capacitação do professor do atendimento educacional especializado da unidade escolar, na escola pesquisa esta atividade não ocorreu. John relata: "Não recebemos nenhum tipo de formação, a não ser a que própria escola oferece, mas isso é difícil de acontecer"; e depois complementa: "Não tenho apoio, quando é necessário tirar dúvidas pergunto diretamente para a professora da sala ou a que fica na sala de recursos, mas isso vai do interesse do educador social".

Mesmo assim o ESV apoia o aluno sempre que a professora não pode fazê-lo. Como ele mesmo relata, o aluno acompanhado já sabia utilizar a máquina braille, o educador social voluntário aprendeu a utilizá-la com o aluno. Contudo, o ESV foi encarregado de apoiar o aluno nas dúvidas que ocorressem durante a escrita com a máquina braille. "Eu fiquei observando e eles me deram a tabelinha de letras, números e pontuação, isso eles me deram para que quando ele estivesse em dúvidas eu pudesse olhar na tabela e falar para ele o código", disse John.

Para o aluno deficiente visual que está aprendendo a escrita, o acompanhamento próximo durante a utilização da máquina braille facilita muito, pois pode tirar suas dúvidas imediatamente. Caso precisasse esperar a professora regular estar livre para fazer isso, o o aluno cego iria ficar sempre atrasado em relação aos demais alunos que, além da professora, podem consultar os demais colegas de classe.

A atuação da ESV Paula começa pelo interesse da mesma em conhecer a "rotina" da sala de aula, seguida da oportunidade de incluir "renda extra" e experiência ao seu currículo. Conforme previsto no edital do programa, Paula auxiliava nas atividade de sala, ajudando com o lanche e as necessidades fisiológicas. Acompanhava também o aluno com deficiência 
nas atividades fora de sala e no intervalo do recreio. Segundo a ESV ela era “como uma babá que ensinava dever".

Paula relata que, embora a sala de apoio estivesse sempre a disposição para ajudar e orientar, o maior apoio que recebia vinha da professora itinerante: "Não recebi nenhum treinamento, só me explicaram o que fazer, me mostraram como a máquina braille funcionava, mas aprender mesmo foi na prática com todo o suporte da sala de apoio, aí sim eles ajudavam, principalmente a professora itinerante que ia umas duas vezes na semana. Teve muita coisa que eu nem cheguei a aprender, que era quando ela ficava com o aluno Y e eu tinha que ficar com o X".

Paula acompanha o aluno X que, segundo ela, além de cego tinha outra doença e tinha o físico bem frágil e também o aluno Y, que era somente cego. "Tinha que ficar de olho" disse Paula. Em relação às atividades com os alunos, Paula comentou que a melhor oportunidade de aprender foi com apoio da professora itinerante, que ia à escola cerca de duas vezes na semana. Nestas visitas a sala de recursos dava todo o suporte para os alunos. Contudo foram poucas oportunidades dela aprender, como o aluno X tinha o conhecimento muito mais raso em relação a turma, seu rendimento na sala de recursos também era muito baixo. Assim sempre que o aluno $\mathrm{Y}$ era chamado para o atendimento na sala de recursos, Paula tinha que acompanhar o aluno X.

Os alunos com deficiência visual dispõem de todo o tempo do ESV, pois são eles os principais responsáveis pelo aluno cego dentro do ambiente escolar. De acordo com Paula, o trabalho designado para eles é ser como uma "babá" desses alunos: "nosso trabalho está em orientar e ajudar os alunos cegos nas atividades de sala de aula, ajudar com o lanche, com as necessidades fisiológicas, acompanhar nas atividades fora da sala de aula e na hora do recreio. Como uma babá que ensina o dever”.

$\mathrm{Na}$ observação, na maior parte do tempo, quando eram passadas atividades, os alunos com deficiência visual recorriam à máquina braille para anotar as respostas das perguntas feitas oralmente pela professora, quando não entendiam, recorriam ao ESV.

Ao descrever sua rotina diária, o ESV John classifica-a como algo básico e prático, que chega na escola por volta de $07 \mathrm{~h}$ e vai diretamente para a sala onde aguarda seu aluno 
chegar e o acompanha em todas as atividades. Relatou que faz leituras para o aluno deficiente visual, e é o responsável por pegar a máquina braille na sala de recursos para a utilização na sala de aula regular, o acompanha até o banheiro e nas atividades recreativas. Quando ele acaba as atividades, fica sem nada para fazer e se ocupa com o celular "esperando a hora passar".

De acordo com o estipulado no programa, o ESV tem que ficar à disposição do aluno a que foi designado, mas, como ele mesmo relata, sua atuação se resume aos momentos em que o deficiente precisa executar uma atividade, que demande de atenção exclusiva. Nas demais atividades do dia, o aluno se ocupa com o que fora planejado pela professora da sala regular, mesmo que esta atividade não o inclua de forma plena. Em tarefas como esta, volta a ser necessária a intervenção e ajuda do ESV.

A observação feita na escola pesquisada permitiu verificar que, o fato de o educador social voluntário estar junto do aluno com deficiência visual, favorece a abertura e o diálogo entre eles, sendo que as alunos cegos recorrem mais a eles do que ao próprio professor. Se a escola possuísse procedimentos bem definidos em relação à inclusão dos alunos com deficiência visual, como por exemplo o que deve ser feito e material que deve ser levado para a sala de aula para facilitar na hora das atividades dos aluno deficiente visual, todo este tempo poderia ser convertido em estudo dirigido para os ESV, visando a capacitação dos mesmos.

Durante as entrevistas com os educadores sociais, houve muitos questionamentos em torno da atuação deles, dos materiais didáticos adaptados que não ficam totalmente a disposição deles em sala de aula, da falta de formação (cursos de braille e soroban, por exemplo) antes de assumir o acompanhamento desses alunos com deficiência visual e também sobre os livros didáticos braille que, segundo eles, ajudaria em um melhor acompanhamento do alunos em relação ao conteúdo trabalhado com a turma.

\subsection{Desafios no processo de inclusão escolar de alunos com deficiência visual}

$\mathrm{Na}$ sala de aula regular os desafios da inclusão são mais evidentes devido à falta de experiência dos professores, de material de apoio, de materiais didáticos transcritos em braille 
e à própria formação dos professores na área da deficiência visual. Por mais que perspectiva da inclusão ainda esteja em processo de construção, ainda falta formação de professores voltada para as necessidades educacionais específicas. "Não fiz cursos na área da deficiência visual. Os cursos que fiz foram apenas da secretaria e falava de inclusão geral”, disse Maria.

Não é uma obrigatoriedade para a conclusão do curso de pedagogia, afirma Lia:

Na faculdade, tive apenas uma disciplina que falava sobre inclusão. E nessa disciplina eu fiz duas visitas em uma escola de ensino especial em Planaltina. Eu tive contato apenas com essa escola, inclusive era para alunos especiais. Foi uma visita de uma manhã, foi o contato maior que eu tive. Entendeu? Então foi esse contato dentro de uma disciplina e dentro dessa disciplina de inclusão que estava no currículo do curso a gente estudou um pouquinho de cada o que era cada coisa. Mas para pegar uma criança e falar que estou apta para trabalhar com essa criança, não! Aí eu fiz LIBRAS, mas por não praticar acabei me esquecendo, sei pouquinha coisa de LIBRAS. Fiz um cursinho porque eu quis, não que me fosse obrigatório essa formação.

Por vezes o professor não sabe como fazer, por não ter tido essa formação, esse complemento na graduação; ele descobre a importância quando se depara com esse aluno em sala, "eu nunca tive interesse de fazer, por não conhecer a deficiência visual e nem outras deficiências. Neste ano, como peguei, eu quis fazer, mas não teve nada que eu soubesse próximo", disse Lia.

Ropoli afirma que a articulação entre professores da sala de recursos e professores da sala de aula regular são necessários e benéficos no que se refere à inclusão e o ensino e aprendizagem de alunos com deficiência:

Os professores comuns e os da Educação Especial precisam se envolver para que seus objetivos específicos de ensino sejam alcançados, compartilhando um trabalho interdisciplinar e colaborativo. As frentes de trabalho de cada professor são distintas. Ao professor da sala de aula comum é atribuído o ensino das áreas do conhecimento, e ao professor do AEE cabe complementar/suplementar a formação do aluno com conhecimentos e recursos específicos que eliminam as barreiras as quais impedem ou limitam sua participação com autonomia e independência nas turmas comuns do ensino regular (ROPOLI et al., 2010, p. 19).

A parceria entre sala de recursos e professores da sala de aula regular é importante para que sejam pensadas estratégias de ensino e inclusão para que o aluno com deficiência visual possa acompanhar a turma com mais facilidade. O professor da sala regular deve saber 
o que existe de material na sala de recursos, deve estar ciente do apoio que pode ter da sala de recursos e, principalmente, o que está sendo trabalhado com o aluno naquele ambiente: "Não sei como funciona ao certo lá na sala de recursos. Eles pegam os meninos as vezes e atendem por lá”, comenta Maria.

Por muitas vezes, o que ajuda no trabalho com o conteúdo são os materiais de apoio que, em algumas instituições, estão disponíveis apenas na sala de recursos e AEE: "Descobri agora em outubro que têm livro literário para o cego na sala de recursos, mas descobri porque eu fui atrás, eu descobri porque falei que não tinha nada, aí que falaram que tinham e vieram me entregar livrinhos", disse Lia. Pelo não conhecimento sobre os materiais e a falta de comunicação entre os docentes das salas de apoio e regulares, professores da sala de aula regular não têm conhecimentos dos materiais e isso implica nas atividades que são passadas de maneira mais difícil. Acontece, também, das atividades que necessitam de adaptação não estarem prontas no tempo previsto: "esse material chegava muito tempo depois pra mim, esse conteúdo, aí já não fazia nem sentido mais trabalhar com a criança aquilo que chegava depois", disse Lia. Pelo atraso do envio das atividades, a adaptação, por vezes, é pensada na hora: "eu tinha que criar métodos próprios, descobri que a massinha de modelar poderia me ajudar com muita coisa, os sinais de pontuação, ensinei tudo com massinha de modelar, fração, eu descobri que ele têm facilidade de sentir o giz de cera na folha se eu fizer o desenho grande. Isso foi tudo na necessidade, descobertas e adequação entre eu e o aluno", disse Lia.

A falta de formação específica dificulta o apoio no ambiente escolar e pode causar um desinteresse pela profissão, alguns professores apenas aceitam o deficiente por não ter opção "sinceramente não gostaria de pegar mais turma assim. Sou temporária e às vezes não têm muita escolha né!", afirma Maria. Outros querem trabalhar com alunos com deficiência, mas não sabem como lidar com a falta tempo e oportunidades: "nesse ano, como peguei, eu quis fazer, mas não teve nada, que eu soubesse, próximo. Moro em Formosa, trabalho no Paranoá e a única coisa que achei foi no Plano Piloto, eu ia chegar em minha casa $8 / 9 \mathrm{~h}$ da noite para acordar às $5 \mathrm{~h}$ da manhã para estar aqui às $7 \mathrm{~h}$, então seria impossível esse trajeto", comenta Lia.

Durante a entrevista, alguns professores demonstraram que o pouco conhecimento na área da inclusão de crianças com deficiência visual que a graduação oferece faz com o que os 
professores do GDF busquem apoio nos Educadores Sociais Voluntários por acreditar que eles tenham recebido a formação necessária. Conforme relata Maria:

Quando aceitei a turma é porque falaram que eu ia ter um monitor e que não precisaria me preocupar, pensei que os monitores saberiam lidar, mas também estão sem saber o que fazer e os meninos ficam perdidos, assim como a gente. A parte boa é que eles convivem com mais pessoas e mais crianças aos cuidados dos monitores e assim despertam vontade de fazer alguma coisa.

Na sala de aula, os planejamentos se fazem comuns, onde todos os alunos da sala recebem as mesmas atividades, o que diferencia o aluno deficiente visual é que ele sempre está aos cuidados do Educador Social Voluntário. "As atividades são as mesmas dos outros alunos, a diferença é que eles têm monitor que auxilia. Vou dando a aula e o monitor vai repassando pra ele", explica Maria.

Observando às leis e normativas federais que visam o suporte e apoio aos alunos com deficiência visual no ambiente escolar, podemos dizer que o GDF têm se esforçado e pensado em meios que podem dar esse suporte e amparo para esses alunos. Porém, ainda necessita de articulação para que a aprendizagem e apoio sejam mais satisfatório. Mesmo que não haja consenso sobre o que realmente deve ser feito para propiciar o melhor suporte aos alunos com deficiência do GDF e, mesmo que o governo já tenha iniciado este projeto para tal, a discussão sobre os rumos deste assunto, conforme o raciocínio de Zardo (ZARDO, 2012), não deve ser dada por encerrada.

Um dos comentários de Lia é que, se o governo enviasse para as escolas os livros didáticos transcritos em braille, facilitaria muito envolver mais os alunos com deficiência visual nas aulas. "O livro da secretaria não chegou pra ele. O livro didático não têm adaptação, nada adaptado." Deve-se priorizar os livros didáticos transcritos em braille para que o aluno cego tenha acesso aos mesmos materiais que os demais alunos da turma. Dentre tantos questionamentos, podemos notar que já percebemos a necessidade de incluir de forma adequada os alunos com deficiência visual e isso nos traz um olhar mais criterioso e ao mesmo tempo crítico para a formação do professor, além da percepção que muitos dos entrevistados falaram sobre a necessidade de especialização específica para o atendimento de 
alunos com deficiência visual. Além dessa percepção por parte dos professores tivemos também os mesmos questionamentos dos Educadores Sociais, que falaram muito da falta de cursos direcionados à deficiência visual e materiais que devem ser utilizados nesse atendimento com o aluno.

O GDF, juntamente com às Regionais de Ensino, estão no caminho certo quando pensaram no Programa ESV para atendimento às pessoas com deficiência. Porém, ainda há de se pensar na qualidade do apoio que está sendo oferecido. As estratégias de especialização na área específica de deficiência visual é necessária para que se alcance um resultado de aprendizagem esperado e que assim a inclusão seja feita de forma satisfatória, além do acesso aos materiais didáticos e livros adaptados para um melhor acompanhamento junto com o restante da turma. Deve se haver investimentos reais pelo governo ao invés de investimentos com programas que visam serviços voluntários e dão o falso entendimento até mesmo pelos que atuam nesse programa como investimento financeiro.

Cursos na área de inclusão devem ser oferecidos sem ônus pelo governo, tanto para professores quanto para pessoas que desejam trabalhar no ambiente educacional no apoio a alunos com deficiência. A inclusão ainda precisa de uma atenção maior em nosso país e os governantes devem estar atentos a isso.

Nossa instituições de ensino podem contribuir através de mais matérias voltadas a temática de inclusão. A formação do professor ainda é vaga nesse aspecto e merece uma atenção também. Investir na formação dos professores contribuirá muito para que os alunos com deficiência visual possam tem um acompanhamento digno. 


\section{CONSIDERAÇÕES FINAIS}

Com intuito de ampliar a inclusão e o acompanhamento de alunos com deficiência no sistema de ensino, tendo em vista as orientações da Política Nacional de Educação Especial na Perspectiva da Educação Inclusiva (MEC, 2008), o GDF buscou, por meio do Programa ESV, dar suporte às atividades de Educação Integral nas Unidades Escolares que desenvolvem atividades de Educação em Tempo Integral e nas escolas de ensino regular onde recebem alunos com deficiência para atuarem no Acompanhamento Educacional Especializado.

O Programa Educador Social Voluntário teve início no ano de 2014 e uma das funções mais importantes desse profissional é o acompanhamento dos alunos com deficiência na sala de aula regular. Também é o maior desafio por não terem, os Educadores Sociais Voluntários, formação, experiência e por não adquirirem nenhuma possibilidade de curso para conhecer os deficientes visuais e suas especificidades.

Devido à falta de conhecimento e também de material disponível em sala de aula, a exemplo do livro didático na escola, por muitas vezes esses profissionais, juntamente com o professor da sala de aula regular não conseguem desenvolver um trabalho que de fato consiga um bom resultado no quesito do ensino e aprendizagem do aluno deficiente visual.

Estamos em um período em que se fala muito de inclusão no geral e da a necessidade de reconhecimento das especificidades de cada deficiência para saber qual tipo de acessibilidade deve ser oferecida. Mesmo sem ter uma pessoa dedicada para ensinar ou treinar os ESV, seria possível utilizá-los para preparação de material didático, específico ou não, uma vez que esta atividade é prevista no edital do programa. A impressão de conteúdo em braille não é executada na sala de recursos da escola pesquisada, contudo a responsabilidade de organização e coleta dos que precisa ser impresso pode ser atividade do ESV. Essas não irão resolver a carência de atendimento especializado aos deficientes visuais, mas pode contribuir para que o espaço e necessidades de materiais dos alunos com deficiência visual em sala de aula regular, se torne mais acessível apenas usufruindo de algo que o próprio programa oferece. 

PARTE III 


\section{PERSPECTIVAS FUTURAS}

Assim encerro mais uma etapa de uma satisfatória caminhada que foi a graduação. Diante de tantas experiências vividas a certeza de que o caminho percorrido foi a melhor escolha e que esse foi apenas o início. Continuar a buscar conhecimentos na área de inclusão dos deficientes visuais e outras deficiências, será minha meta constante. Os estudos não param por aqui. A busca de meios de inclusão e a aprendizagem desses alunos foi o que me moveu e a esperança de poder contribuir para que tenham uma educação e verdadeira inclusão é o que continuará a me mover.

Espero poder contribuir muito com a educação de alunos com deficiência e que eu consiga concluir os projetos em torno dessa temática.. Então é necessário que eu, citando a Walt Disney, "continue a nadar”. Realizar meus objetivos de ingressar na educação inclusiva pública do Distrito Federal e alcançar minha meta de ser uma profissional referência. Colocar em prática o que me foi passado durante a graduação me espelhando nos grandes mestres que tive. Que Deus continue à minha frente. O que parece ser o fim, é apenas o começo. 


\section{REFERÊNCIAS}

BRASIL. Lei $N^{\circ}$ 9394, de 20 de dezembro de 1996. Lei de Diretrizes e Bases da Educação Nacional. Disponível em <http://www. Planalto. gov. br/ccivil_03/leis/19394.htm>. Acesso em 18/04/2019, v. 30, 2015.

\section{Política Nacional de Educação Especial na Perspectiva da Educação Inclusiva.} Brasília: MEC/SEESP, 2008.

Estatuto da Pessoa com Deficiência. Lei No 13. 146, de 6 de julho de 2015. Institui a Lei Brasileira de Inclusão da Pessoa com Deficiência (Estatuto da Pessoa com Deficiência). Disponível em <http://www. planalto.gov.br/ccivil_03/_ato2015-2018/2015/lei/113146.htm> Acesso em 19/04/2019, Brasília, DF: Presidência da República.

DISTRITO FEDERAL. Orientação Pedagógica - Educação Especial. Secretaria de Estado de Educação do Distrito Federal, 2010.

Portaria 354, de $1^{\circ}$ de novembro de 2018. Secretaria de Estado de Educação do Governo do Distrito Federal. Estratégia de Matrícula. Distrito Federal: SEEDF, 2019.

. Secretaria de Estado de Educação do Governo do Distrito Federal. Currículo em movimento da educação básica: educação especial. Distrito Federal: SEEDF, 2018.

. Secretaria de Estado de Educação do Governo do Distrito Federal. Regimento

Interno. Disponível em $<$ http://www.se.df.gov.br/wp-conteudo/uploads/2017/08/Regimento_Interno_05-07-2018.pdf $>$ Acesso em 13/06/2019.

. Projeto Político Pedagógico. Centro de Ensino Especial para Deficientes Visuais do Distrito Federal, 2018.

CRUZ NETO, Otávio. O trabalho de campo como descoberta e criação. In: MINAYO, Maria Cecília de Souza; DESLANDES, Suely Ferreira; CRUZ NETO, Otávio; GOMES, Romeu. Pesquisa social: Teoria, método e criatividade. 21. ed. Petrópolis: Editora Vozes, 1994. p. 51-66.

FIGUEIREDO, Rita Vieira de. A formação de professores para a inclusão dos alunos no espaço pedagógico da diversidade. In: MANTOAN, Maria Teresa Eglér (Org.). O desafio das diferenças nas escolas. Petrópolis: Editora Vozes, 2008. p. 141-145.

GASKELL, George. Entrevistas individuais e grupais. In: BAUER, Martin W.; GASKELL, George. Pesquisa qualitativa com texto, imagem e som: Um manual prático. 2. ed. Petrópolis: Editora Vozes, 2002. p. 64-89.

GIL, Antonio Carlos. Como elaborar projetos de pesquisa. 4. ed. São Paulo: Atlas, 2002. 
GOMES, Romeu. A análise de dados em pesquisa qualitativa. In: MINAYO, Maria Cecília de Souza; DESLANDES, Suely Ferreira; CRUZ NETO, Otávio, GOMES, Romeu. Pesquisa social: Teoria, método e criatividade. 21. ed. Petrópolis: Editora Vozes, 1994. p. 67-80.

IBGE, IBGE. Censo demográfico 2010. IBGE: Instituto Brasileiro de Geografia e, 2010.

INEP. Censo Escolar. Disponível em: $<$ http://portal.inep.gov.br/sinopsesestatisticas-da-educacao-basica>. Acesso em: 13 jun. 2019.

MEC. Dia Mundial do Braille reflete sobre atendimento aos cegos. 2018. Disponível em: $<$ http://portal.mec.gov.br/ultimas-noticias/202-264937351/58921-dia-mundial-do-braille-refle te-sobre-atendimento-aos-cegos>. Acesso em 09 jul. 2019

MANZINI, Eduardo José. Formação continuada do professor para atender à Educação Inclusiva. Ensaios Pedagógicos: Programa Educação Inclusiva: direito à diversidade, Brasília, p.77- 84, 2007.

NOZU, Washington Cesar Shoiti; ICASATTI, Albert Vinicius; BRUNO, Marilda Moraes Garcia. Educação inclusiva enquanto um direito humano. Inclusão Social, v. 11, n. 1, 2017.

ROPOLI, Edilene Aparecida et al. A Educação Especial na Perspectiva da Inclusão Escolar: a escola comum inclusiva. Brasília: Ministério da Educação, Secretaria de Educação Especial: Universidade Federal do Ceará, 2010. Disponível em: $<$ http://portal.mec.gov.br/index.php?option=com_docman\&view=download\&alias=7103-fasc iculo-1- pdf\&Itemid=30192 3>

VILLAS BOAS, Denise Cintra; FERREIRA, Léslie Piccolotto; VIOLA, Izabel Cristina. Professor especializado na área da deficiência visual: os sentidos da voz. Rev. soc. bras. fonoaudiol., São Paulo, v. 17, n. 1, p. 92-100, Mar. 2012.

ZARDO, Sinara Pollom. Direito à educação: a inclusão de alunos com deficiência no ensino médio e a organização dos sistemas de ensino. 2012. 


\title{
Universidade de Brasília
}

\section{APÊNDICE A - \\ TERMO DE CONSENTIMENTO LIVRE E ESCLARECIDO}

Prezado(a) professor(a) da sala de recursos

Você está sendo convidado(a) para participar da pesquisa relacionada ao Projeto do Governo do Distrito Federal "Educador Social Voluntário", destacando o atendimento educacional para estudantes com deficiência visual desenvolvida pela graduanda Joselena Patricio da Silva Santos sob orientação da professora Dra ${ }^{\mathrm{a}}$. Sinara Pollom Zardo, da Faculdade de Educação da Universidade de Brasília.

Sua participação na presente pesquisa é muito importante e consistirá no fornecimento de informações por meio de entrevista semiestruturada e questionário de perfil. Caso aceite participar, concorda com o uso das informações que serão analisadas apenas para fins acadêmicos. A qualquer momento você poderá desistir de participar, sem prejuízos para sua parte, assim como você poderá ter acesso aos responsáveis pela pesquisa. Garantimos o sigilo das informações prestadas já que nenhum participante será identificado. Gostaríamos muito de contar com sua colaboração.

Considerando que fui informado(a) da relevância do estudo proposto, e da importância de minha participação, declaro o meu consentimento em participar da pesquisa, como também concordo que os dados obtidos sejam utilizados apenas para fins acadêmicos.

Brasília, de de 2018.

\author{
Assinatura do(a) entrevistado(a) \\ Para qualquer esclarecimento, segue contato: Professora Dra ${ }^{\mathrm{a}}$. Sinara Pollom \\ Zardo (sinarazardo@gmail.com).
}

Agradecemos sua contribuição em nossa pesquisa. 


\section{Universidade de Brasília}

\section{APÊNDICE B -}

\section{Questionário de perfil do entrevistado - professor(a) da sala de recursos}

Nome (apenas para organização dos dados da pesquisa):

1) Qual o seu sexo?

( ) Feminino ( ) Masculino ( ) Outro.

2) Qual sua idade?

3) Sobre a formação inicial (graduação)

3. 1 Qual sua área de formação?

3. 2 Em qual instituição você realizou sua graduação?

3. 3 Ano de conclusão da sua graduação:

4) Sobre pós-graduação:

4. 1 Você possui curso de pós-graduação: ( ) Sim ( ) Não

4. 2 Qual o nível?

( ) Especialização. Área e ano de conclusão:

( ) Mestrado. Área e ano de conclusão:

( ) Doutorado. Área e ano de conclusão:

( ) Pós-Doutorado. Área e ano de conclusão:

5) Sobre formação continuada (cursos de extensão ou aperfeiçoamento):

5. 1 Você tem participado de cursos de formação continuada? ( ) Sim ( ) Não

5. 2 Em caso afirmativo, sobre quais temas? 
5. 3 Os cursos foram oferecidos pela SEEDF ou você que financiou a própria formação continuada: ( ) SEEDF ( ) Financiamento próprio

5. 4 Você realizou algum curso na área da educação especial? ( ) Sim ( ) Não

5. 5 Você realizou algum curso sobre a temática da deficiência visual? ( ) Sim ( ) Não

6) Sobre a experiência profissional:

6. 1 Tempo de atuação na área da Educação:

6. 2 Tempo de atuação na SEEDF:

6. 3 Tempo de atuação na instituição local:

6. 4 Tempo de atuação na atual função: 


\section{Universidade de Brasília}

\section{APÊNDICE C - \\ Questionário de perfil do entrevistado - professor(a) da sala de aula regular}

Nome (apenas para organização dos dados da pesquisa):

1) Qual o seu sexo?

( ) Feminino ( ) Masculino ( ) Outro.

2) Qual sua idade?

3) Sobre a formação inicial (graduação)

3. 1 Qual sua área de formação?

3. 2 Em qual instituição você realizou sua graduação?

3. 3 Ano de conclusão da sua graduação:

4) Sobre pós-graduação:

4. 1 Você possui curso de pós-graduação: ( ) Sim ( ) Não

4. 2 Qual o nível?

( ) Especialização. Área e ano de conclusão:

( ) Mestrado. Área e ano de conclusão:

( ) Doutorado. Área e ano de conclusão:

( ) Pós-Doutorado. Área e ano de conclusão:

5) Sobre formação continuada (cursos de extensão ou aperfeiçoamento):

5. 1 Você tem participado de cursos de formação continuada? ( ) Sim ( ) Não

5. 2 Em caso afirmativo, sobre quais temas? 
5. 3 Os cursos foram oferecidos pela SEEDF ou você que financiou a própria formação continuada: ( ) SEEDF ( ) Financiamento próprio

5. 4 Você realizou algum curso na área da educação especial? ( ) Sim ( ) Não

5. 5 Você realizou algum curso sobre a temática da deficiência visual? ( ) Sim ( ) Não

6) Sobre a experiência profissional:

6. 1 Tempo de atuação na área da Educação:

6. 2 Tempo de atuação na SEEDF:

6. 3 Tempo de atuação na instituição local:

6. 4 Tempo de atuação na atual função: 


\section{Universidade de Brasília}

\section{APÊNDICE D - \\ Questionário de perfil do entrevistado - educador(a) social voluntário}

Nome (apenas para organização dos dados da pesquisa):

1) Qual o seu sexo?

( ) Feminino ( ) Masculino ( ) Outro.

2) Qual sua idade?

3) Qual seu nível de escolaridade?

( ) ensino médio completo

( ) ensino médio incompleto

( ) educação de jovens e adultos completo

( ) educação de jovens e adultos incompleto

( ) ensino superior completo

( ) ensino superior incompleto

4. Em caso de possuir graduação concluída:

4. 1 Qual sua área de formação?

4. 2 Em qual instituição você realizou sua graduação?

4. 3 Ano de conclusão da
graduação: 
5) Há quanto tempo você atua como educador(a) social?

6) Você tem alguma formação específica na área da educação inclusiva? ( ) sim ( ) não

6. 1 Se sim, qual?

7) Você tem alguma formação específica na área da deficiência visual?

8) Quais atividades abaixo relacionadas você desenvolve na escola:

- Auxiliar na organização do material pedagógico

- Desenvolver projetos e oficinas com os estudantes

- Acompanhar os alunos nas horas de refeições e de higiene pessoal

- Estimular a interação social entre colegas

( ) Outra. 


\section{Universidade de Brasília}

\section{APÊNDICE E - \\ Roteiro de entrevista professor(a) da sala de recursos e da sala de aula regular}

1) Fale um pouco sobre o seu processo de formação e como tornou-se professora do atendimento educacional especializado.

2) Quanto tempo atua como docente? Você já havia trabalhado com alunos com deficiência visual?

3) Na sua formação, você teve contato com conteúdos sobre a educação especial?

4) E em relação à deficiência visual, fez algum curso de formação específico?

5) Como é feito o planejamento do AEE? Quais são as atividades realizadas com os alunos com deficiência visual?

6) Como os alunos com deficiência visual são avaliados no AEE?

7) Há articulação entre o trabalho realizado na sala de recursos e o trabalho realizado na sala de aula? Como?

8) Como você percebe a inclusão escolar? Cite pontos positivos e negativos.

9) Não tenho mais perguntas. Você gostaria de acrescentar algo? 


\section{Universidade de Brasília}

\section{APÊNDICE F - \\ Roteiro de entrevista educador(a) social}

1) Fale um pouco sobre você e quais motivos te levaram a atuar como educador social.

2) Há quanto tempo você atua nessa função?

3) Como foi o processo seletivo? Você que escolheu atuar nessa instituição?

4) A escolha de atuar nos anos iniciais do ensino fundamental foi sua?

5) Você que escolheu atuar em turmas inclusivas? E com alunos com deficiência visual?

6) Ao ingressar na atividade de educador social, você recebeu algum tipo de formação?

7) Fale um pouco sobre sua rotina na escola.

8) Você recebe algum tipo de apoio?

9) Quais os desafios que você enfrenta na atuação como educador social?

10) Não tenho mais perguntas. Você gostaria de fazer mais algum comentário. 